\title{
Spatial and temporal oxygen isotope variability in northern Greenland - implications for a new climate record over the past millennium
}

\author{
S. Weißbach ${ }^{1}$, A. Wegner ${ }^{1}$, T. Opel ${ }^{2}$, H. Oerter ${ }^{1}$, B. M. Vinther ${ }^{3}$, and S. Kipfstuhl ${ }^{1}$ \\ ${ }^{1}$ Alfred-Wegener-Institut, Helmholtz-Zentrum für Polar- und Meeresforschung, Bremerhaven, Germany \\ ${ }^{2}$ Alfred-Wegener-Institut, Helmholtz-Zentrum für Polar- und Meeresforschung, Potsdam, Germany \\ ${ }^{3}$ Centre for Ice and Climate, Niels Bohr Institute, University of Copenhagen, Copenhagen, Denmark
}

Correspondence to: S. Weißbach (stefanie.weissbach@awi.de)

Received: 7 May 2015 - Published in Clim. Past Discuss.: 23 June 2015

Revised: 7 October 2015 - Accepted: 19 January 2016 - Published: 3 February 2016

\begin{abstract}
We present for the first time all $12 \delta^{18} \mathrm{O}$ records obtained from ice cores drilled in the framework of the North Greenland Traverse (NGT) between 1993 and 1995 in northern Greenland. The cores cover an area of $680 \mathrm{~km} \times 317 \mathrm{~km}$, $10 \%$ of the Greenland ice sheet. Depending on core length (100-175 m) and accumulation rate (90-200 $\mathrm{kg} \mathrm{m}^{-2} \mathrm{a}^{-1}$ ) the single records reflect an isotope-temperature history over the last 500-1100 years.

Lowest $\delta^{18} \mathrm{O}$ mean values occur north of the summit and east of the main divide as a consequence of Greenland's topography. In general, ice cores drilled on the main ice divide show different results than those drilled east of the main ice divide that might be influenced by secondary regional moisture sources.

A stack of all NGT records and the NGRIP record is presented with improved signal-to-noise ratio. Compared to single records, this stack represents the mean $\delta^{18} \mathrm{O}$ signal for northern Greenland that is interpreted as proxy for temperature. Our northern Greenland $\delta^{18} \mathrm{O}$ stack indicates distinctly enriched $\delta^{18} \mathrm{O}$ values during medieval times, about $\mathrm{AD} 1420 \pm 20$ and from AD 1870 onwards. The period between $\mathrm{AD} 1420$ and $\mathrm{AD} 1850$ has depleted $\delta^{18} \mathrm{O}$ values compared to the average for the entire millennium and represents the Little Ice Age. The $\delta^{18} \mathrm{O}$ values of the 20th century are comparable to the medieval period but are lower than that about AD 1420.
\end{abstract}

\section{Introduction}

During the past decades the Arctic has experienced a pronounced warming exceeding that of other regions (e.g., Masson-Delmotte et al., 2015). To place this warming in a historical context, a profound understanding of natural variability in past Arctic climate is essential. To do so, studying climate records is the first step. However, meteorological measurements in the Arctic are only available for relatively short time periods; only a few time series start as early as in the 19th century. Hence, proxy data from climate archives such as ice cores from the polar ice caps are essential.

Studying the climate of the past centuries allows us to compare the instrumental data with proxy records and therefore to assess the quality of the proxies for climate reconstructions.

Stable water isotopes (here $\delta^{18} \mathrm{O}$ ) in ice cores are commonly used to derive paleotemperatures (e.g., Fischer et al., 1998c; Johnsen et al., 2000; Steffensen et al., 2008). They are largely controlled by equilibrium and kinetic fractionation processes during evaporation at the ocean surface, along the poleward air-mass transport and condensation of precipitation, depending on temperature and moisture conditions (Dansgaard et al., 1969; Jouzel and Merlivat, 1984; Merlivat and Jouzel, 1979).

The isotope ratio is not only driven by local temperature but also affected by several factors like moisture sources and their proximity to the deposition site, the topography of the ice sheet and the seasonality of precipitation (Fisher et al., 1985). In addition the isotope signal is altered by 
post-depositional processes like wind-induced redistribution of snow, temperature gradient metamorphism and diffusion (Johnsen et al., 2000; Pinzer et al., 2012; Steen-Larsen et al., 2014). Stacked records are used to compensate for effects due to local to regional differences and to improve the signal-to-noise ratio (Fisher et al., 1985; Masson-Delmotte et al., 2015; White et al., 1997).

To date, most ice core studies on the Greenland ice sheet have been carried out point-wise (e.g., Dye 3, GRIP, GISP2, NGRIP), which begs the question of how representative one single long ice core record is for deriving a comprehensive record of past climate. A study of ice cores from southern Greenland revealed that winter season stable water isotopes are largely influenced by the North Atlantic Oscillation (NAO) and are strongly related to southwestern Greenland air temperatures. On the other hand, summer season stable water isotope ratios show higher correlations with North Atlantic sea surface temperature conditions (Vinther et al., 2010). In particular, northern Greenland has been little investigated so far. The summit in Greenland's center is the highest site and separates Greenland into a northern and southern part. Northern Greenland differs significantly from the south in terms of lower air temperatures and lower snow accumulation rates (Fischer et al., 1998c). Thus, the results from southern Greenland are not directly transferable to the northern part.

Northern Greenland's climate is influenced by different effects than the southern part. One example is the NAO effect, which is present in the southern and western part of Greenland and is discussed to be reduced in northern Greenland (Appenzeller et al., 1998).

The cyclones causing the precipitation over northern Greenland originate in the Baffin Bay and bring dry and cold air masses from the central Arctic to northern Greenland (Chen et al., 1997).

The dominant westerly winds are blocked by the ice divide, while the northeastern part has very low accumulation rates below $100 \mathrm{~kg} \mathrm{~m}^{-1} \mathrm{a}^{-1}$.

The topographic situation in northern Greenland is special for $\delta^{18} \mathrm{O}$ studies. In northern Greenland going northward also means to go downward (lower altitudes).

For a correct estimate of mass balances as well as the response to the ongoing climate change, knowledge of accumulation rates and the spatial distribution of $\delta^{18} \mathrm{O}$ as a temperature proxy is important for the entire Greenland ice sheet. However, due to northern Greenland's remoteness its recent past climate has, up to now, been only scarcely investigated.

Even in the 1990s little was known about northern Greenland. Only few studies had been performed before the Alfred Wegener Institute's (AWI) North Greenland Traverse (NGT) started in 1993. There had been a traverse by Koch and Wegener in 1913 (Koch and Wegener, 1930) and one by Benson in 1952-1953 (Benson, 1962), and there was the British North Greenland Expedition in 1958 (Bull, 1958), which studied the accumulation rate in northern Greenland. How- ever, there had been no stable water isotope studies in the central part of northern Greenland. Fischer et al. (1998c) and (Schwager, 2000) present the first results from $\delta^{18} \mathrm{O}$ values of some of the NGT records.

Using the updated accumulation rates of the (compared to Friedmann et al., 1995; Schwager, 2000) NGT, it was possible to show that the area of lower accumulation rates is much larger than expected before, which has an influence on the outlet glaciers (Weißbach et al., 2015).

The NGT ice cores offer, for the first time, the possibility to study the spatial and temporal variability in stable oxygen isotope records from northern Greenland. Furthermore, they allow the analysis of the common spatial stable water isotope signal in northern Greenland by stacking the individual records to significantly reduce the isotopic noise that is present in a single record due to local peculiarities.

The main objectives of this study are (1) to investigate the spatial variability in $\delta^{18} \mathrm{O}$ in northern Greenland using this new set of $\delta^{18} \mathrm{O}$ data and to evaluate the influence of isotopic noise on a single record, (2) to assess whether stable water isotope records from sites with low accumulation rates can be interpreted as climate signals, (3) to present a new robust stacked $\delta^{18} \mathrm{O}$ record for northern Greenland covering the past millennium, and (4) to interpret this record in terms of paleoclimate with respect to temporal variability and relation to large-scale climate information from other proxy records.

\section{Material and methods}

The ice cores presented here were drilled during the NGT from 1993 to 1995. In total, 13 ice cores (B16-B23, B26B30) from 12 different sites (Table 1, Fig. 1) were drilled along the traverse route. The ice cores cover the last 5001000 years. The drillings were accompanied by extensive surface snow studies (e.g., Schwager, 2000).

B21 and B23 as well as B26 to B30 are located on ice divides (Fig. 1), while B16-B20 were drilled east of the main ice divide. The NGRIP core (North Greenland Ice Core Project Members, 2004) was drilled $14.5 \mathrm{~km}$ northwest of $\mathrm{B} 30$ following the main ice divide and is therefore included in this study.

Before analyzing the stable water isotopes, a density profile of each core was measured. To do so, the single core segments (approximately $1 \mathrm{~m}$ long) were weighed in the field. Additional higher-depth-resolution density records were determined using gamma-absorption measurements in the AWI cold lab (Wilhelms, 1996). Finally, in 2012, density of the first $70 \mathrm{~m}$ of the three cores B19, B22 and B30 was analyzed by X-ray computer tomography (X-CT; Freitag et al., 2013).

An exponential function fitted to the data taking into account all three types of density data with same respect was used to calculate water equivalent (w.e.) accumulation rates and to synchronize the cores. 
Table 1. Overview of all NGT drill sites.

\begin{tabular}{lcccc}
\hline Core & Core length & Elevation & \multicolumn{2}{c}{ Geographic position } \\
\cline { 4 - 5 } ID & $(\mathrm{m})$ & $(\mathrm{m}$ a.s.1. $)$ & $\begin{array}{c}\text { Latitude } \\
\left({ }^{\circ} \mathrm{N}\right)\end{array}$ & $\begin{array}{c}\text { Longitude } \\
\left({ }^{\circ} \mathrm{W}\right)\end{array}$ \\
\hline B16 & 102.4 & 3040 & 73.94 & 37.63 \\
B17 & 100.8 & 2820 & 75.25 & 37.63 \\
B18 & 150.2 & 2508 & 76.62 & 36.40 \\
B19 & 150.4 & 2234 & 78.00 & 36.40 \\
B20 & 150.4 & 2147 & 78.83 & 36.50 \\
B21 & 100.6 & 2185 & 80.00 & 41.14 \\
B22 & 120.6 & 2242 & 79.34 & 45.91 \\
B23 & 150.8 & 2543 & 78.00 & 44.00 \\
B26 & 119.7 & 2598 & 77.25 & 49.22 \\
B27 & 175.0 & 2733 & 76.66 & 46.82 \\
B28 & 70.7 & 2733 & 76.66 & 46.82 \\
B29 & 110.5 & 2874 & 76.00 & 43.50 \\
B30 & 160.8 & 2947 & 75.00 & 42.00 \\
\hline
\end{tabular}

Selected parts of B30 were also analyzed for electrolytic conductivity using high-resolution continuous-flow analysis (Kaufmann et al., 2008).

For the isotopic measurements the ice was cut into samples of $1-5 \mathrm{~cm}$ depth resolution, corresponding to $2-10 \mathrm{sam}-$ ples per year. Most of the ice was sampled with $2-2.5 \mathrm{~cm}$ depth resolution. Only at the uppermost parts of the core were samples cut with lower depth resolution (up to $5 \mathrm{~cm}$ ). For some meters of special interest a resolution of $1 \mathrm{~cm}$ was used. After melting, $\delta^{18} \mathrm{O}$ was determined using Delta $\mathrm{E}$ and $\mathrm{S}$ mass spectrometers from Finnigan MAT in the AWI laboratory with uncertainties less than $0.1 \% o$ as determined from long-term measurements. Cores B27 and B28 were drilled at the same site. Parts of core B27 (8.25-11.38 m w.e.), corresponding to AD 1926-1945) were lost, and these were replaced by the record from B28. For the other parts, the mean of both dated cores was calculated to generate one isotope record for this site.

Six of the NGT cores (B16, B18, B20, B21, B26 and B29) were already dated up to a certain depth by annual layer counting (using density, major ions or $\delta^{18} \mathrm{O}$ ) in prior studies (e.g., Fischer and Mieding, 2005; Fischer et al., 1998a, b; Schwager, 2000). Depending on the availability of data and differences in snow accumulation rates the dating quality of these cores varies between 1- and 5-year accuracy. For the other NGT cores annual layer counting was not possible due to the very low accumulation rates $\left(<100 \mathrm{~kg} \mathrm{~m}^{-2} \mathrm{a}^{-1}\right)$. To achieve the same dating quality for all NGT cores for better comparison and to apply the dating on the whole core length, we used a new dating procedure for all cores. From density-corrected (w.e.) high-resolution electrical conductivity profiles (Werner, 1995; Wilhelms, 1996) and $\mathrm{SO}_{4}^{2-}$ concentration profiles for B16, B18, B21 (Fischer et al., 1998a, b), B20 (Bigler et al., 2002) and an electrolytic conductivity profile (B30), distinct volcanic horizons were iden-

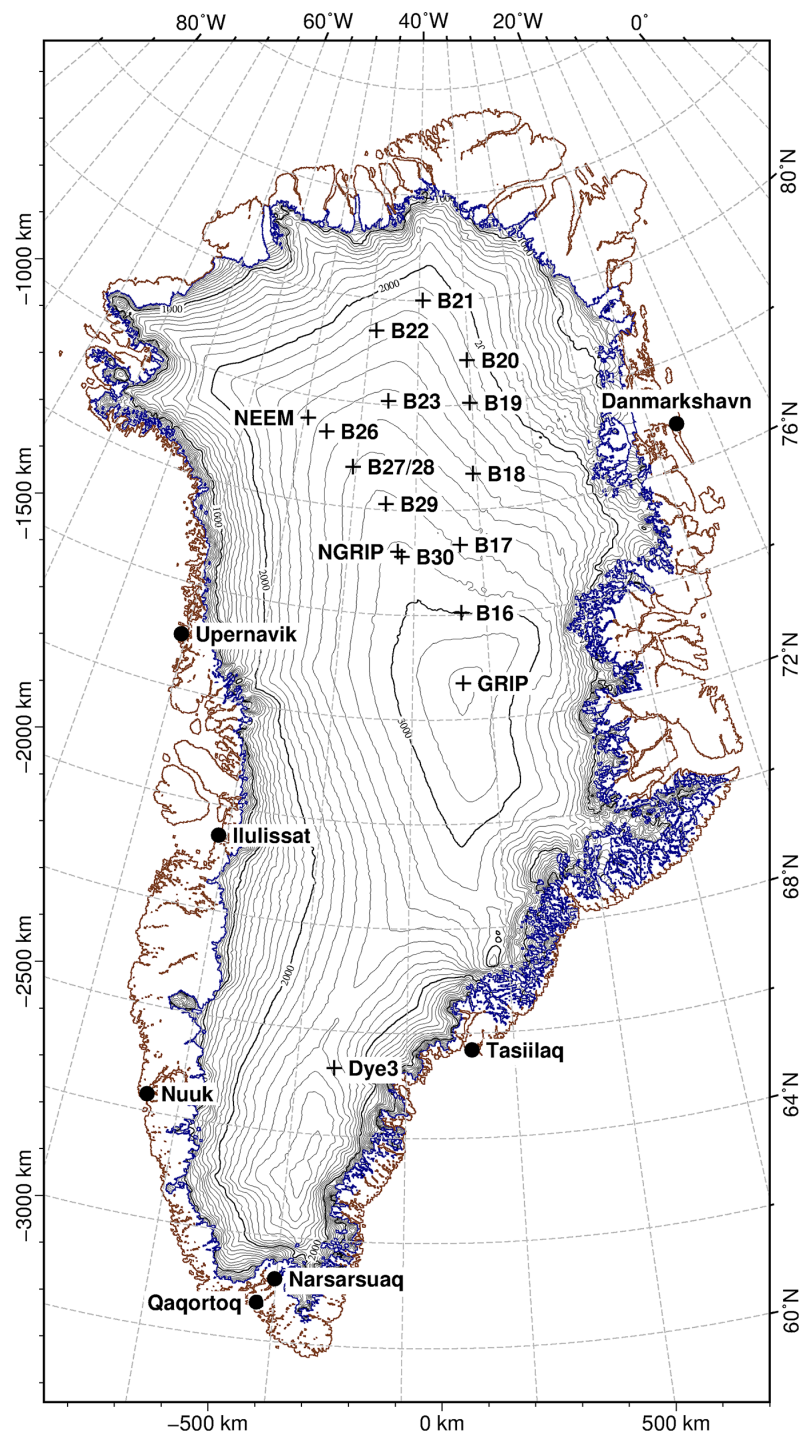

Figure 1. Map of Greenland with NGT ice cores (B16-B23, B26B30 crosses), deep drilling sites (crosses) and towns (black dots). The ice surface topography is according to Bamber et al. (2013), (mapping: Polar Stereographic (WGS84), Standard Parallel 71, Latitude of Projection Origin -39).

tified and used as match points to synchronize the cores (Table 2). Some of the volcanic eruptions show a more pronounced signal in the Greenlandic ice than others. Thus not all eruptions could be identified in every record.

Between match points, the annual dating was assigned assuming a constant snow accumulation rate. If a volcanic match point could not be clearly identified in an ice core, the next time marker was used to calculate the mean accumulation rate. Below the deepest volcanic match point, the last calculated accumulation rate was extrapolated until the end of the core. As the cores were drilled only in the upper part of the ice sheet (up to 100-175 m depths), layer thinning was not taken into account. 
Table 2. Depth of volcanic horizons used for dating. The given year is the time of aerosol deposition on the Greenland ice sheet. All depths are given in meter water equivalent. If a horizon could not be clearly identified a dash is shown in the table. A field is empty if the horizon is deeper than the length of the ice core. The maximum difference is estimated from a comparison between cores dated by annual layer counting (Mieding, 2005; Schwager, 2000) and the dating used for this study. Also given are the volcanic explosivity index (VEI; Newhall and Self, 1982) and the total Northern Hemisphere stratospheric sulfate aerosol injection (Gao et al., 2008) for each volcanic eruption used.

\begin{tabular}{|c|c|c|c|c|c|c|c|c|c|c|c|c|c|c|c|c|}
\hline Year [AD] & Event & B16 & B17 & B18 & B19 & B20 & B21 & B22 & B23 & B26 & $\mathrm{B} 27$ & B28 & B29 & B30 & VEI & Sulfate \\
\hline 1912 & Katmai* & 11.60 & 9.31 & 8.48 & 7.38 & 7.86 & 8.62 & 11.56 & 9.49 & 14.27 & 13.69 & 14.44 & 11.41 & 13.12 & 6 & 11.0 \\
\hline 1816 & Tambora* & 24.49 & 20.27 & 18.91 & 16.77 & 17.27 & 19.46 & 26.17 & 21.54 & 31.50 & 31.13 & 31.91 & 25.97 & 29.91 & 7 & 58.7 \\
\hline 1783 & Laki* & 29.36 & 24.19 & 22.45 & 19.94 & 20.32 & 23.10 & 31.25 & 25.93 & 37.77 & 37.19 & 38.07 & 31.28 & 35.80 & 4 & 93.0 \\
\hline 1739 & Tarumai* & 35.52 & - & 26.90 & 24.10 & 24.62 & - & - & - & - & - & & - & 43.07 & 5 & 0 \\
\hline 1694 & Hekla** & - & 34.47 & 31.84 & 28.54 & 29.16 & 32.87 & 44.06 & - & - & - & & 44.22 & 50.45 & 4 & 0 \\
\hline 1666 & Unknown** & 46.22 & - & 34.75 & 31.20 & 32.10 & 35.93 & 48.13 & - & - & - & & 48.50 & - & & 0 \\
\hline 1640 & Komagatake** & 49.90 & - & 37.48 & 33.69 & 34.80 & - & - & - & - & - & & 52.36 & - & 4 & 33.8 \\
\hline 1601 & Huaynaputina* & & 44.97 & 41.62 & - & 38.70 & 42.95 & - & 48.31 & 69.22 & 68.39 & & 58.25 & 65.94 & 4 & 46.1 \\
\hline 1479 & Mt. St. Helens ${ }^{* *}$ & & 58.84 & 54.42 & - & 51.31 & 56.04 & 75.09 & - & & 89.42 & & 76.81 & 86.60 & & 7.4 \\
\hline 1259 & Samalas* & & & 76.60 & 68.03 & 72.86 & & & 89.35 & & 126.10 & & & 122.10 & & 145.8 \\
\hline 1179 & Katla* & & & - & - & 80.04 & & & 98.60 & & & & & & & 0 \\
\hline 934 & Eldgjá* & & & 109.20 & 99.20 & & & & & & & & & & & 0 \\
\hline \multicolumn{2}{|c|}{ Max. age of core [AD] } & 1470 & 1363 & 874 & 753 & 775 & 1372 & 1372 & 1023 & 1505 & 1195 & 1763 & 1471 & 1242 & & \\
\hline \multicolumn{2}{|c|}{ Max. difference [a] } & 7 & & 3 & & 8 & 6 & & & 4 & & & 3 & & & \\
\hline
\end{tabular}

* Sigl et al. (2013); ** Friedmann et al. (1995).

\section{Results and discussion}

\subsection{Depth-age models and snow accumulation rates}

The last millennium was a volcanically active time (Sigl et al., 2013). The volcanic aerosols deposited on the Greenland ice sheet can be used as time markers. The depths of peaks in conductivity and sulfate concentration attributed to certain volcanic horizons are given in Table 2 as used for our dating approach.

During the last 500 years, the time period between two detectable eruptions at NGT sites does not exceed 100 years for any of the cores. This leads to a dating uncertainty for each core of smaller than 10 years compared to the annually counted timescales (Mieding, 2005; Schwager, 2000), which is minimal at the matching points. The three youngest volcanic reference horizons (Katmai, Tambora and Laki) and the eruptions from AD 1257 (Samalas; Lavigne et al., 2013) and AD 934 (Eldgjá) were found in all cores, whereas the other eruptions could not be clearly identified in every ice core. We could not find a common pattern (e.g., distance, strength of the eruption) regarding whether or not volcanic horizons could be observed in all records.

This already indicates a high spatial variability within the study region related to significant influences of local to regional peculiarities (e.g., wind drift or sastrugi formation). An overview of the resulting mean accumulation rates for the entire core lengths for all NGT drilling sites, as well as the respective ranges, is given in Table 3 . According to our dating, the cores reaching furthest back in time are B18, B19 and B20, covering more than the last 1000 years. These northeasterly cores have the lowest accumulation rates with values below $100 \mathrm{~kg} \mathrm{~m}^{-2} \mathrm{a}^{-1}$ (B19: $94 \mathrm{~kg} \mathrm{~m}^{-2} \mathrm{a}^{-1}$; B20: $98 \mathrm{~kg} \mathrm{~m}^{-2} \mathrm{a}^{-1}$ ), whereas the highest mean accumulation rate is found for B27/28 in the southwest of our study region with
$180 \mathrm{~kg} \mathrm{~m}^{-2} \mathrm{a}^{-1}$. Generally, the accumulation rate decreases from the sites located on the main ice divide in the southwest of the study area to the northeast.

The observed range of accumulation at one single site is highest for the southwestern cores (B30 and B29) ranging between 137 and $161 \mathrm{~kg} \mathrm{~m}^{-2} \mathrm{a}^{-1}$ (B29). Lowest values are found for the cores east of the main ice divide (e.g., B17, B18 and B19) ranging between 113 and $119 \mathrm{~kg} \mathrm{~m}^{-2} \mathrm{a}^{-1}$ (B17).

The length of the records varies depending on accumulation rate and total length of the core. The longest records are from B19 (back to AD 753) and B20 (back to AD 775). The following comparisons of the individual records refer to the longest common time frame (AD 1505-1953). Although diffusion is known to change isotopic values in the snow, in this study the data were not corrected for diffusion effects. While diffusion length is in the range of annual layer thickness, diffusion might be affecting the absolute difference in isotope content of neighboring years, but the mean over 11 or 30 years will not be affected.

\subsection{Regional variability in $\delta^{18} \mathrm{O}$ in northern Greenland}

Annual mean $\delta^{18} \mathrm{O}$ records of the NGT cores are displayed in Fig. 2. Table 4 summarizes the main $\delta^{18} \mathrm{O}$ characteristics of each core.

The lowest mean $\delta^{18} \mathrm{O}$ values $(\sim-37 \%$ ) in northern Greenland (B16-B18) and possibly the lowest in Greenland are found east of the main ice divide and north of the summit, but not at the summit as might be expected. Also, the lowest firn temperatures were measured at B160-B18 (Table 4). This is in contrast to the findings of Ohmura (1987), who suggested temperatures similar to the summit for this region. 


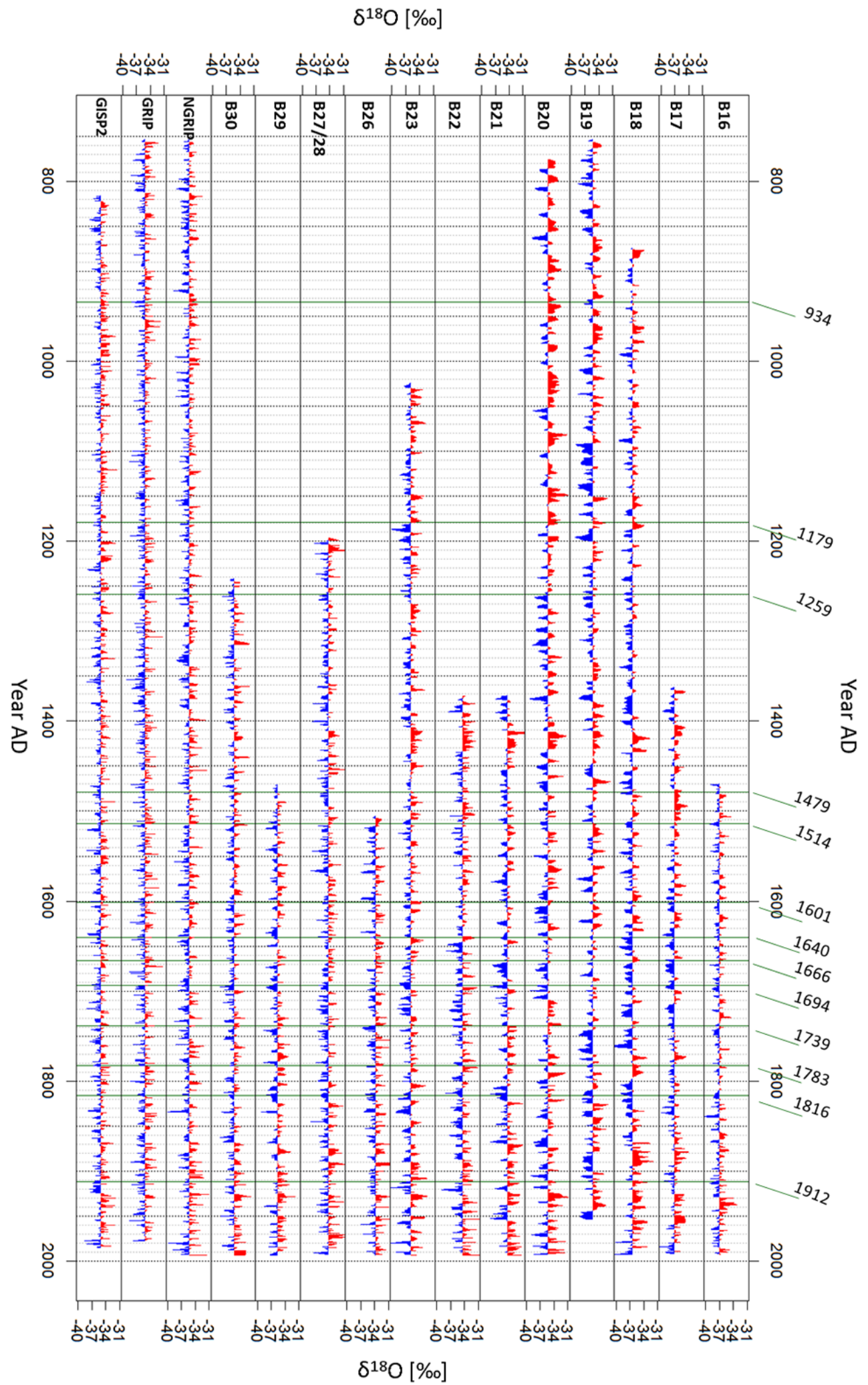

Figure 2. Annual $\delta^{18} \mathrm{O}$ records at the 12 NGT sites (this study) and NGRIP (Vinther et al., 2006b), GRIP (Vinther et al., 2010) and GISP2 (Grootes and Stuiver, 1997). Blue values are those below the mean over their common time frame (AD 1505-1953) and red are the higher ones. Dark-green vertical lines mark the volcanic eruptions (years given at top) used as time markers. 
Table 3. Resulting mean accumulation rates (from the surface to the deepest volcanic horizon and in brackets for their common time frame (AD 1505-1953)) for each NGT drill site, the lowest and highest rate within the whole core length, the time period from surface to the deepest volcanic horizon, and the age at the bottom of the ice core calculated by extrapolation of the deepest calculated accumulation rate.

\begin{tabular}{lrrrr}
\hline Core & $\begin{array}{r}\text { Mean accumulation rate } \\
{\left[\mathrm{kg} \mathrm{m}^{-2} \mathrm{a}^{-1}\right]}\end{array}$ & $\begin{array}{r}\text { Accumulation rate range } \\
{\left[\mathrm{kg} \mathrm{m}^{-2} \mathrm{a}^{-1}\right]}\end{array}$ & $\begin{array}{r}\text { Time period } \\
{[\text { AD] }}\end{array}$ & $\begin{array}{r}\text { Age at bottom of core } \\
{[\text { AD] }}\end{array}$ \\
\hline B16 & $141[141]$ & $134-148$ & $1640-1993$ & 1470 \\
B17 & $114[114]$ & $113-119$ & $1479-1993$ & 1363 \\
B18 & $103[106]$ & $100-110$ & $934-1993$ & 874 \\
B19 & $94[94]$ & $90-99$ & $934-1993$ & 753 \\
B20 & $98[100]$ & $90-105$ & $1179-1994$ & 775 \\
B21 & $109[109]$ & $105-113$ & $1479-1994$ & 1372 \\
B22 & $145[145]$ & $141-154$ & $1479-1994$ & 1372 \\
B23 & $121[122]$ & $116-132$ & $1179-1994$ & 1023 \\
B26 & $176[176]$ & $172-190$ & $1601-1995$ & 1505 \\
B27/B28 & $180[181]$ & $165-187$ & $1783-1995$ & 1195 \\
B29 & $149[150]$ & $137-161$ & $1479-1995$ & 1471 \\
B30 & $166[169]$ & $158-178$ & $1259-1995$ & 1242 \\
\hline
\end{tabular}

Table 4. The $15 \mathrm{~m}$ firn temperature, mean annual $\delta^{18} \mathrm{O}$ values for each ice core, the range of the highest and lowest $\delta^{18} \mathrm{O}$ values and the year they occurred as well as the standard deviation (SD) all given for their common time frame (AD 1953-1505).

\begin{tabular}{lrrrrrr}
\hline Core & $\begin{array}{r}15 \mathrm{~m} \text { firn } \\
\text { temperature }\left[{ }^{\circ} \mathrm{C}\right]\end{array}$ & $\begin{array}{r}\text { Mean } \delta^{18} \mathrm{O} \\
{[\% \text { ] }}\end{array}$ & $\begin{array}{r}\delta^{18} \mathrm{O} \text { range } \\
{[\% \text { ] }}\end{array}$ & $\begin{array}{r}\text { Years [AD] of } \\
\text { lowest/highest value }\end{array}$ & $\begin{array}{r}\mathrm{SD} \delta^{18} \mathrm{O} \\
{[\% \text { ] }}\end{array}$ & $\begin{array}{r}\text { Time period [AD] } \\
\text { (whole core length) }\end{array}$ \\
\hline B16 & $-32.5^{* * *}$ & -37.07 & -40.64 to -33.11 & $1839 / 1937$ & 0.99 & $1470-1993$ \\
B17 & $-32.3^{* * *}$ & -37.13 & -40.06 to -33.89 & $1835 / 1879$ & 1.08 & $1363-1993$ \\
B18 & $-32.3^{* * *}$ & -36.53 & -41.52 to -31.75 & $1761 / 1889$ & 1.44 & $874-1993$ \\
B19 & $-30.9( \pm 0.5)^{* *}$ & -35.49 & -38.97 to -31.77 & $1575 / 1826$ & 1.32 & $753-1953$ \\
B20 & $-30.4^{* * *}$ & -35.41 & -39.34 to -30.69 & $1699 / 1929$ & 1.42 & $775-1994$ \\
B21 & $-30.1^{* * *}$ & -34.53 & -38.29 to -30.95 & $1814 / 1871$ & 1.29 & $1372-1994$ \\
B22 & $-29.8^{* * *}$ & -34.54 & -39.11 to -29.84 & $1921 / 1953$ & 1.34 & $1372-1994$ \\
B23 & $-29.3( \pm 0.5)^{* *}$ & -35.98 & -42.11 to -32.23 & $1918 / 1928$ & 1.28 & $1023-1994$ \\
B26 & $-30.3^{* * *}$ & -33.86 & -37.22 to -29.42 & $1597 / 1893$ & 1.25 & $1505-1995$ \\
B27/B28 & $-30.6( \pm 0.5)^{* *}$ & -34.47 & -38.26 to -30.58 & $1566 / 1892$ & 1.25 & $1195-1995$ \\
B29 & $-31.6( \pm 0.5)^{* *}$ & -35.65 & -39.22 to -31.59 & $1834 / 1928$ & 1.18 & $1471-1995$ \\
B30 & $-31.8( \pm 0.5)^{* *}$ & -35.46 & -38.53 to -31.52 & $1862 / 1928$ & 1.09 & $1242-1988$ \\
NGRIP* & & -35.42 & -40.12 to -30.81 & $1836 / 1928$ & 1.24 & \\
\hline
\end{tabular}

* Vinther et al. (2006b); ${ }^{* *}$ Schwager (2000); ${ }^{* * *}$ interpolated from Schwager (2000).

Generally, the cores located east of the main ice divide show lower mean $\delta^{18} \mathrm{O}$ values than those located on the ice divide (Fig. 3a). For instance, B29 and B30 are at similar altitudes and latitudes to B16 and B17 but show significantly higher values (Fig. 3a).

Figure 4 indicates that accumulation, latitude and altitude may have a minor impact on the $\delta^{18} \mathrm{O}$ values here. One possible explanation would be additional moisture isotopically depleted during the transport from directions farther north.

The cores more to the north (B19-B22) were drilled at lower altitude and therefore record different climate signals (i.e., from lower air masses) compared to the high-altitude ice cores that, in turn, record a more smoothed signal of higher atmospheric layers. Similar effects were observed, for exam- ple, in Svalbard (Isaksson et al., 2005), even though at considerably lower altitudes compared to Greenland.

The maximum difference in mean $\delta^{18} \mathrm{O}$ values of individual ice cores is $3.3 \%$ o (highest mean $\delta^{18} \mathrm{O}$ in $\mathrm{B} 26:-33.86 \%$; lowest mean $\delta^{18} \mathrm{O}$ in $\mathrm{B} 17:-37.13 \%$ ). The standard deviation (SD) for the annual mean values within each core in the common time frame (AD 1505-1953) is lowest for B16 $(0.99 \%$ ) and highest for B18 $(1.44 \%)$. We found no general relation between accumulation rate and standard deviation of the $\delta^{18} \mathrm{O}$ values for all individual cores, even though the northern cores with generally lower accumulation rates show higher standard deviations than the southern cores.

The correlation coefficients between the annual $\delta^{18} \mathrm{O}$ records of individual ice cores are relatively small $(r=0.1$ to $0.36, p<0.05)$. This can be partly explained by the fact 

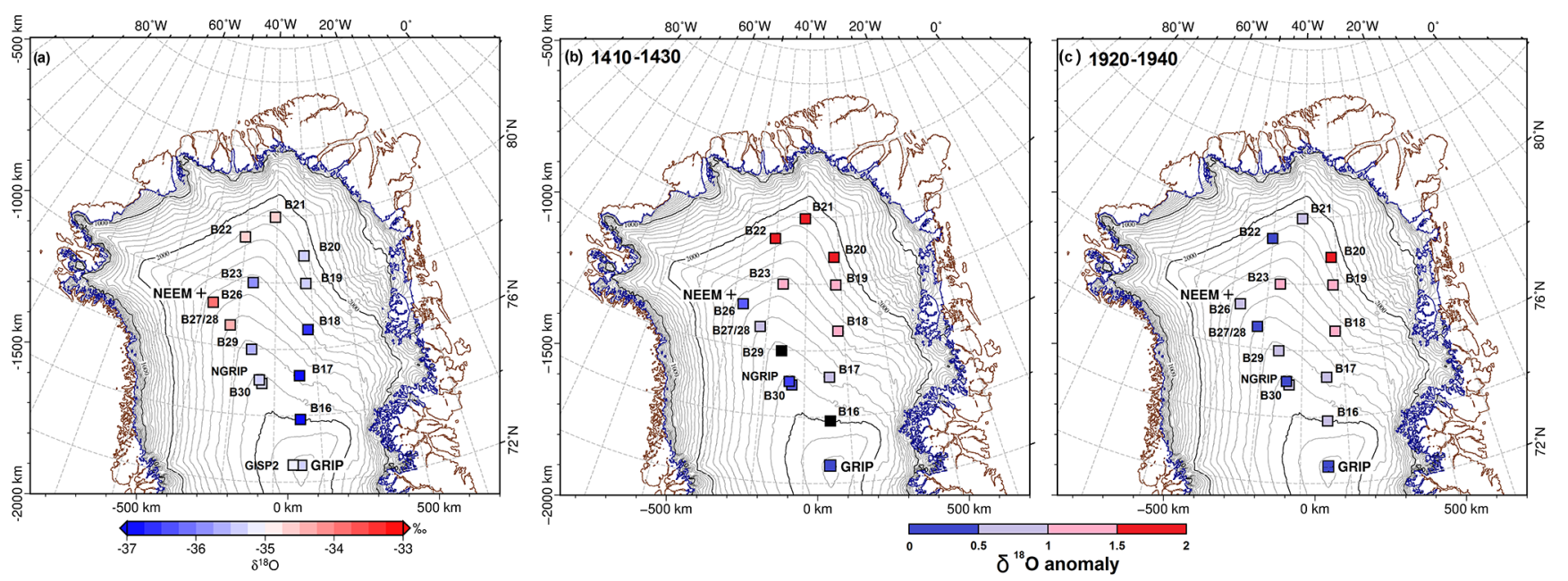

Figure 3. Spatial distribution of $\delta^{18} \mathrm{O}$ values in northern Greenland. (a) The mean $\delta^{18} \mathrm{O}$ values of the northern Greenland ice cores in their common time frame (AD 1505-1953) are shown with color-coded squares. Blue colors represent lower values and red colors higher values. Mapped mean anomalies of $\delta^{18} \mathrm{O}$ compared to (a) for two different periods: (b) AD 1410-1430 and (c) AD 1920-1940. If a record does not cover the required time period the square is filled in black.

that the 13 northern Greenland (NG) drilling sites (12 NGT and NGRIP) are up to $680 \mathrm{~km}$ apart from each other. In other studies where correlated cores are drilled closer together, at one drill site, higher correlation coefficients were found (e.g., at GRIP $r=0.41-0.55-$ White et al., 1997; or at NEEM $r \sim 0.54$ - Masson-Delmotte et al., 2015). The strongest correlations are found for the cores from the southwest (B26B30) and the lowest for those from the northeast (B19, B20). There is a significant linear relationship between the distance between the core sites and their annual $\delta^{18} \mathrm{O}$ correlation coefficient $(r=-0.44, p<0.05)$. However, it is not always true that the cores with smallest distance between them have the highest correlations.

For smoothed values (11-year running mean) the correlation coefficients between the $\delta^{18} \mathrm{O}$ records are only slightly higher. Only $50 \%$ of the combinations have coefficients higher than 0.3 , and $14 \%$ are lower than 0.1 . This indicates an important influence of regional site-to-site differences. Variability in $\delta^{18} \mathrm{O}$ is dependent on local (e.g., wind), regional (e.g., position on the ice sheet) and large-scale (e.g., circulation patterns) processes. Even adjacent cores may differ considerably according to snow drift (Fisher et al., 1985). One further reason for the rather low correlations may be attributed to dating uncertainties.

From Fig. 2, we compare our individual NGT $\delta^{18} \mathrm{O}$ records to other published central to northern Greenland (GRIP, GISP2, NGRIP) $\delta^{18} \mathrm{O}$ time series. Prominent decadal-scale maxima and minima occurred mostly isochronally. However, specific events such as warm periods around AD 1420 or AD 1920-1930 or a cold period in the 17th century are more pronounced in the NGT cores compared to summit records.

In Fig. 2 is also obvious that some records show faster changes between warmer and colder events (e.g., GRIP, B30 and B26), while others (e.g., B17-B21) remain longer at values higher or lower than their mean (Fig. 2). The longest warm period (compared to the mean of whole core length) is found in B19 (with 37 subsequent years warmer than the mean), while B17 has the longest cold period (28 subsequent years colder than mean). GRIP, B26, and B27/28 show a higher frequency with a maximum of about 10 subsequent warmer or colder years. A frequency analysis of 11-year running mean smoothed data supports these findings. B18-B21 and B29 show much longer main periods (117-248 a) than B16-B17 and B22-B30 (besides B29, 81-39 a).

In general, the first half of the last millennium was characterized by longer warm or cold anomalies than the second half and records with more rapid fluctuations are from the summit and the main ice divide, while those cores drilled east of the divide have longer periods of positive or negative anomalies. We conclude that, east of the divide, the climate conditions are not as variable and therefore the annual $\delta^{18} \mathrm{O}$ signal is of greater persistence.

The east-to-west difference is also expressed by the dependency of $\delta^{18} \mathrm{O}$ values on longitude (Fig. 4). This is in line with results from Box (2002), who found that there is often an opposite trend in air temperatures in east and west Greenland. The antiphase of temperature records from east and west Greenland is possibly explained by the importance of different weather regimes (e.g., Ortega et al., 2014).

The range in $\delta^{18} \mathrm{O}$ in the different cores is different, too. Cores drilled in the northeast that are characterized by the lowest accumulation rates have the highest standard deviations (SD) in $\delta^{18} \mathrm{O}$, which can be partly explained by the fact that a smaller number of accumulation events scatter more easily. 


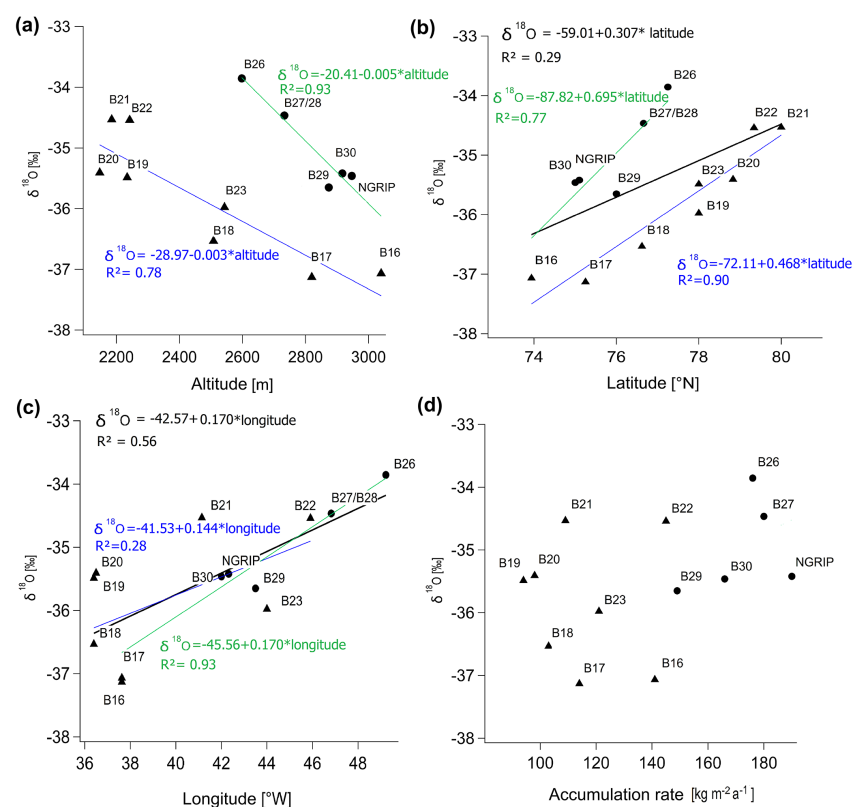

Figure 4. Mean $\delta^{18} \mathrm{O}$ (AD 1505-1953) as a function of (a) altitude, (b) latitude, (c) longitude and (d) accumulation rate of northern Greenland ice core drill sites. Cores with higher accumulation rates $\left(>145 \mathrm{~kg} \mathrm{~m}^{-2} \mathrm{a}^{-1}\right)$ are given as black dots and lower rates as black triangles, which is similar to the differentiation between east of and on the main ice divide. For statistically significant correlations the lines give the linear regression functions (black: mean; green: higher accumulation rates; blue: lower accumulation rates).

We investigated the relationship between the altitude, latitude and longitude of the drilling sites and the mean $\delta^{18} \mathrm{O}$ values (Fig. 4a, b, c), which are, when considering all records, statistically significant $(p<0.05)$ only for longitude and latitude. Regarding their snow accumulation rate we differentiate between two groups: (i) cores with accumulation rates lower than $145 \mathrm{~kg} \mathrm{~m}^{-2} \mathrm{a}^{-1}$ mainly located east of the main ice divide (B16-B21 and B23) and (ii) cores with higher accumulation rates (B22, B26-B30 and NGRIP). We find higher $\delta^{18} \mathrm{O}$ ratios for sites with higher accumulation rates (Fig. 4d). The relationship is weak but becomes stronger for higher accumulation rates. Buchardt et al. (2012) noted that the relationship between accumulation rate and $\delta^{18} \mathrm{O}$ is not distinct for Greenland. Furthermore, Buchardt et al. (2012) found that the sensitivity of $\delta^{18} \mathrm{O}$ changes to accumulation rate is smallest in northeastern Greenland (North Central and North 1972), which is in agreement with our findings.

Among the factors influencing the mean isotopic composition, longitude has the strongest impact $\left(R^{2}=0.56\right)$, which becomes clearest when looking only at the data of group I $\left(R^{2}=0.93\right)$. Figure $4 \mathrm{c}$ shows the clear east-to-west gradient in the mean $\delta^{18} \mathrm{O}$ values in northern Greenland.

If separating between group I ("East") and group II ("Divide") there is a strong altitude effect $\left(R^{2}=0.93\right.$ and 0.78$)$ in the data, too.
These patterns may be explained by different atmospheric circulation conditions allowing additional moisture from other sources to reach the region east of the ice divide. This is supported by the finding of Friedmann et al. (1995), who suppose, based on data from B16 to B19, that northeastern Greenland receives more moisture from local sources as the Greenland Sea, Atlantic Ocean and the Canadian wetlands, in particular during summer.

We found lower $\delta^{18} \mathrm{O}$ values in the southern and eastern part of northern Greenland in contrast to the general ideas of Dansgaard (1954), who expected lower values northward. That we do not find the lowest values north is a consequence of different factors in northern Greenland that balance each other out. More to the north, where we would expect lower $\delta^{18} \mathrm{O}$ values, the altitude in northern Greenland is decreasing, which causes higher $\delta^{18} \mathrm{O}$ values (Fig. 1). A multiple linear regression becomes necessary, as Johnsen et al. (1989) did before.

Applying this approach to our data, we find $\delta\left(\delta^{18} \mathrm{O}\right) /(\delta$ (latitude $)=-0.30 \quad( \pm 0.40) \%_{\text {o degree }}{ }^{-1} \quad$ and $\delta\left(\delta^{18} \mathrm{O}\right) / \delta$ (altitude) $=-0.0035 \quad( \pm 0.0024) \%$ o $\mathrm{m}^{-1}$. The regression residuals are linearly related to longitude as well as accumulation rate.

In general, we found correlations with altitude, latitude and longitude, but the balancing-out effects because of the special topography in northern Greenland have to be taken into account.

To study the regional-scale patterns of common variability in all annual $\delta^{18} \mathrm{O}$ records, we performed a principal component analysis (PCA). All calculations are done for the largest common time frame of all cores (AD 1505-1953). Other time periods were used as well, and they show similar results.

Only the first two principal components (PC1 and PC2) are above the noise level. The first two eigenvectors of the isotopic time series explain $34.1 \%$ of the total variance (PC1: $21.8 \%$; PC2: $12.3 \%$ ). PC1 is similar to the mean of all records $(r=0.97, p \ll 0.01)$. It was not possible to assign PC2 to any climatic relevant signal. The other PCs are dominant in one or two records but are not significant for the total variance of the entire data set. The loading patterns show a homogeneous pattern for EOF1 and a bipolar (west-east) result for EOF2.

To summarize, the spatial differences in mean $\delta^{18} \mathrm{O}$ values in northern Greenland can be largely explained by the influence of the topography of the ice sheet on the regional climate system. The main ice divide influences the pathways of air masses, causing lower accumulation rates in the east.

We assume that the temporal variability in a stacked NG $\delta^{18} \mathrm{O}$ record represents past temperature development.

\subsection{The northern Greenland $\delta^{18} \mathrm{O}$ stack and its paleoclimatic significance}

Stable water isotope ratios in ice are widely used as a proxy for air temperature (Dansgaard, 1964; Johnsen et al., 
1995; Jouzel et al., 1997b). The comparison to direct airtemperature observation data and proxy data allows for assessment of the quality of the proxy in terms of paleoclimatological interpretation.

To reduce the noise in the single $\delta^{18} \mathrm{O}$ records, we calculated a stacked record by averaging the 13 annual $\mathrm{NG} \delta^{18} \mathrm{O}$ records in their overlapping time periods (NG stack, Fig. 5). Before stacking, all records were centered and normalized regarding their common time frame (AD 1505-1953). The SD of the NG stack (0.44 for AD 1505-1953) is less than half of the SD in annual $\delta^{18} \mathrm{O}$ records of the individual cores. Vinther et al. (2010) also point out that stacking is important to improve the signal-to-noise ratio in areas with low accumulation rate. Local drift noise accounts for half of the total variance in single-site annual series (Fisher et al., 1985). As the NG stack before AD 1000 is based on only four records ( $<25 \%$ of the total core numbers), we decided to focus in the following only on the time period after AD 1000.

As the NG stack is a result of 13 ice cores over a large area, we assume it is regionally representative.

To investigate the relationship of the NG stack with air temperature, we used monthly meteorological observations from coastal southwestern Greenland sites and Stykkishólmur in northwestern Iceland available from the Danish Meteorological Institute (DMI; http://www.dmi.dk; AD 17841993) and the Icelandic Met Office (http://en.vedur.is/; back to AD 1830), respectively. We selected only the Greenlandic temperature records longer than 200 years for our study even though they are at a large distance to the NGT drill sites (706-2206 km).

The correlation coefficients between the NG stack and these air-temperature records are shown in Table 5. Dating uncertainties are taken into account by comparing 5year running means. The NG stack shows low but significant $(p<0.001)$ correlations with the air temperatures at all sites (Table 5).

The strongest correlation with annual mean temperature was found for the merged station data at Greenland's southeast coast $(r=0.51)$, and the temperature reconstruction for the North Atlantic Arctic boundary region of Wood et al. (2010) $(r=0.55)$; the lowest was also found for Qaqortoq $(r=0.39)$ in the south of Greenland (Table 5). For Stykkishólmur the correlation is in the range of the Greenlandic ones $(r=0.41)$. Slightly higher correlations are obtained by comparing the NG stack to seasonal data. Except for Ilulissat, winter months (DJF) show weaker correlations; spring (MAM) and summer (JJA) months show stronger correlations with the NG stack.

Comparably low correlations between annual $\delta^{18} \mathrm{O}$ means and measured temperatures from coastal stations are also reported for the NEEM record (Steen-Larsen et al., 2011).

However, the rather low correlation coefficients might underestimate the real regional $\delta^{18} \mathrm{O}$-temperature relations because of different reasons.
We expect that the most important reasons are the large distances and the difference in altitude (i.e., more than $2000 \mathrm{~m}$ ) between drill sites and the meteorological stations, which cause them to receive different atmospheric signals. The stations are located at the coast and are in turn also likely influenced by local factors such as the occurrence of sea ice.

One other aspect might be seasonality, as argued by SteenLarsen et al. (2011) for the NEEM site. The snowfall in northern Greenland may be unevenly distributed seasonally. However, it is not possible to generate sub-annual data for northern Greenland ice cores due to low accumulation rates. We find a tendency towards stronger correlation between the annual $\delta^{18} \mathrm{O}$ and summer (JJA, $r=0.35-0.51$ ) and spring (MAM, $r=0.36-0.62$ ) temperatures for most of the stations. This points to a higher proportion of summer snow in the annual accumulation in northern Greenland, too. SON has slightly weaker correlation coefficients $(r=0.31-0.5)$, while DJF is only significant for Ilulissat and the merged southern station.

In addition, regional noise factors such as wind drift and sastrugi formation as well as uncertainties in ice core dating and the usage of very old observation data have to be taken into account.

In summary, we consider the northern Greenland $\delta^{18} \mathrm{O}$ stacked record as a reliable proxy for annual temperature for northern Greenland. The regional representativeness of the NG stack is supported by the general similarity to the NEEM $\delta^{18} \mathrm{O}$ record (Masson-Delmotte et al., 2015) for the period AD 1724-1994. We found a strong correlation between both records ( $r=0.83$ for 30-year running mean). Even single events such as the highest values in AD 1928 and the AD 1810-1830 cooling occur in both records.

Although the NG stack record shows some correlation with temperature data from coastal Greenland sites, it remains an open question as to how the NG stack $\delta^{18} \mathrm{O}$ variations can be converted into absolute temperature changes within northeastern Greenland during the last millennium. In the past, such conversion of isotopic time series of Greenland ice cores was based on a modern analogue approach taking the observed spatial isotope-temperature gradient of $0.67 \pm 0.2 \%{ }^{\circ} \mathrm{C}^{-1}$ (Dansgaard, 1964; Johnsen et al., 1989) as a valid calibration for converting isotope records of Greenland ice cores into temperature changes (e.g., Grootes et al., 1993). The strong confidence of glaciologists in this approach came principally from two observations. (1) Over both polar ice sheets, the spatial correlation between modern isotope and annual mean temperature is very high and significant. (2) This empirical observation was theoretically understood as a consequence of a Rayleigh rainout system controlling the isotopic composition of meteoric water.

However, for the Greenland area this long-accepted approach has been challenged during the last decade. Two entirely independent analytic techniques, one based on the numerical interpretation of borehole temperatures (e.g., DahlJensen et al., 1998) and the other based on the occlusion pro- 


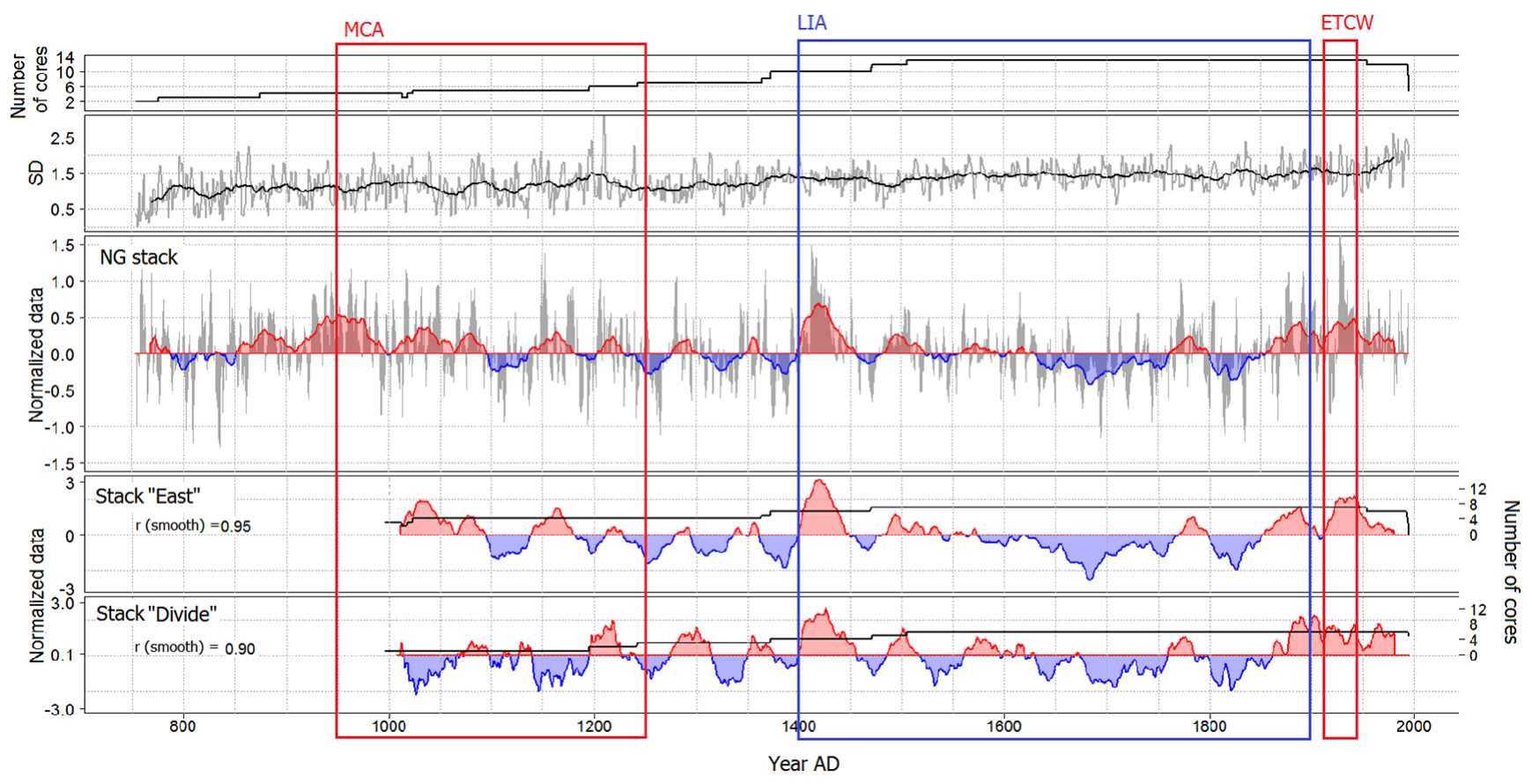

Figure 5. Top two panels: the number of cores used for the stack and the standard deviation (SD; gray: annual values; black: 30-year running mean) of all times. Middle: annual stacked $\delta^{18} \mathrm{O}$ (gray) and smoothed record (30-year running mean). Values more enriched compared to the mean (AD 1953-1505) are shown in red, while values less enriched are shown in blue. Known climate anomalies are marked: Medieval Climate Anomaly (MCA, AD 950-1250; Mann et al., 2009), the Little Ice Age (LIA, AD 1400-1900; Mann et al., 1998), and early twentieth century warming (ETCW, 1920-1940; Semenov and Latif, 2012; Wood and Overland, 2010). Bottom two panels: 30-year running mean on $z$ levels (centered and normalized data) of stacked northern Greenland $\delta^{18}$ O records over the last 1000 years. Stack "East": B16, B17, B18, B19, B20, B21 and B23. Stack "Divide": B22, B26, B27, B29, B30 and NGRIP. Values in red are more enriched compared to the mean over their last 1000 years, and those in blue are less enriched. Also given is the correlation coefficient of 30-year running means between the NG stack and the sub-stacks (AD 1505-1993). The coefficient for a similar correlation between the two sub-stacks is calculated with $r=0.71$.

cess of gases into the ice (e.g., Buizert et al., 2014; Severinghaus et al., 1998), allow for a direct temperature reconstruction at least for some periods of the past. In agreement with this, both methods point to much lower temporal $\delta^{18} \mathrm{OT}^{-1}$ slopes ranging between 0.4 and $0.3 \% 0^{\circ} \mathrm{C}^{-1}$ (Jouzel et al., 1997a). Consequently, they indicate a much higher temperature variability in Greenland during the last glacial period. For the period of the last 9000 years the Greenland average Holocene isotope-temperature relationship has been estimated to be $0.44-0.53 \% 0^{\circ} \mathrm{C}^{-1}$, again substantially lower compared to the modern spatial gradient (Vinther et al., 2009). However, as all these studies cover much longer time periods as compared to our NG stack records, no firm conclusion can be drawn from these studies about an appropriate isotope-temperature relationship for the last millennium.

Along the NGT firn, temperature measurements at about $15 \mathrm{~m}$ depth have been done (Table 4). However, due to their small range of about $2 \mathrm{~K}$ difference, it is difficult to reassess the general Greenland isotope-temperature relationship from Johnsen et al. (1989) from the NGT data alone. Schwager (2000) added data from Dansgaard et al. (1969) from along the EGIG traverse, which was also used in Johnsen et al. (1989), to expand the temperature range to derive a more reliable isotope-temperature gradient. This calculated gradient of $0.7 \pm 0.2 \% 0^{\circ} \mathrm{C}^{-1}$ is within the gradient uncertainty range given by Johnsen et al. (1989). Using our updated NGT data set we get the same results.

If we apply the spatial isotope-temperature gradient of $0.7 \% 0^{\circ} \mathrm{C}^{-1}$ from Schwager (2000) for the range of isotope variations $(-1.4$ to $2.5 \%$ o ) of the NG stack record, the isotope data translate into temperature changes of -2.0 to $3.6^{\circ} \mathrm{C}$ $(5.6 \mathrm{~K})$ within the last millennium. However, applying instead a temporal gradient of $0.48 \% 0^{\circ} \mathrm{C}^{-1}$ as suggested by Vinther et al. (2009) results in possible temperature changes of -2.9 to $5.2^{\circ} \mathrm{C}(8.1 \mathrm{~K})$ within the last 1000 years. Using the most recent temporal glacial-interglacial isotopetemperature gradients reported by Buizert et al. (2014) would result in comparable temperature changes. If using the NEEM gradient of $1.1 \pm 0.2 \% 0^{\circ} \mathrm{C}^{-1}$ (Masson-Delmotte et al., 2015), which is valid for AD 2007-1979 in the area of NEEM, the resulting temperature range of the NG stack is, at -1.3 to $2.3^{\circ} \mathrm{C}(3.6 \mathrm{~K})$, a bit smaller than compared to the Johnsen or Schwager gradient. Nevertheless, the resulting temperature ranges are larger than expected (e.g., Dahl- 
Table 5. Correlation coefficients ( $r$ ) of the stacked $\delta^{18} \mathrm{O}$ record with annual and seasonal (DJF, MAM, JJA and SON) extended Greenland temperature records * (Vinther et al., 2006a), northwestern Iceland instrumental data** (Hanna et al., 2004; Jónsson, 1989), annual mean Greenland ice sheet near-surface air temperatures from combined instrumental and model output *** (Box et al., 2009) and Arctic temperature reconstruction ${ }^{* * * *}$ (Wood et al., 2010). All correlations are done with 5-year running means and are significant at the $95 \%$ level $(p<0.05)$.

\begin{tabular}{|c|c|c|c|c|}
\hline \multirow[b]{2}{*}{ Merged South (Greenland)* } & \multirow{2}{*}{$\begin{array}{r}r_{\text {annual }} \\
0.51\end{array}$} & \multicolumn{2}{|c|}{$r_{\text {seasonal }}$} & \multirow{2}{*}{$\begin{array}{r}\text { Years of overlap } \\
1784-1994\end{array}$} \\
\hline & & DJF & 0.47 & \\
\hline & & MAM & 0.62 & \\
\hline & & JJA & 0.51 & \\
\hline & & SON & 0.5 & \\
\hline \multirow[t]{4}{*}{ Ilulissat (Greenland)* } & 0.46 & DJF & 0.50 & 1784-1994 \\
\hline & & MAM & 0.42 & \\
\hline & & JJA & 0.36 & \\
\hline & & SON & 0.45 & \\
\hline \multirow[t]{4}{*}{ Nuuk (Greenland)* } & 0.41 & DJF & - & 1784-1994 \\
\hline & & MAM & 0.55 & \\
\hline & & JJA & 0.47 & \\
\hline & & SON & 0.47 & \\
\hline \multirow{4}{*}{ Qaqortoq (Greenland)* } & 0.39 & DJF & - & 1784-1994 \\
\hline & & MAM & 0.50 & \\
\hline & & JJA & 0.50 & \\
\hline & & SON & 0.36 & \\
\hline \multirow{4}{*}{ Stykkishólmur (Iceland) ${ }^{* *}$} & 0.41 & DJF & - & 1830-1994 \\
\hline & & MAM & 0.36 & \\
\hline & & JJA & 0.35 & \\
\hline & & SON & 0.31 & \\
\hline Mean Greenland surface air temperature ${ }^{* * *}$ & 0.50 & & & 1840-1994 \\
\hline Extended instrumental temperature record ${ }^{* * * *}$ & 0.55 & & & $1802-1994$ \\
\hline
\end{tabular}

Jensen et al., 1998), which is an additional argument for not calculating absolute temperatures from the NG stack with the given gradients.

We conclude that any conversion of the NG stack isotope record into absolute temperature variations during the last millennium is highly uncertain. Thus, for the following part of the manuscript, we will refer to NG stack isotope anomalies as relative temperature changes in terms of "warmer" (i.e., isotopically enriched) and "colder" (isotopically depleted) only, but will refrain from converting our ice core data into absolute temperature changes.

To assess regional differences within northern Greenland, stacks of subsets of cores will be discussed in terms of interpretation as a temperature proxy. As illustrated in Fig. 4, we differentiate between two different types of cores: cores drilled on the ice divide and cores drilled east of the ice divide. Accordingly, in Fig. 5 the overall northern Greenland $\delta^{18} \mathrm{O}$ stack used in this study is compared to a stack of the cores of lower accumulation rate drilled east of the main ice divide (B16, B17, B18, B19, B20, B21 and B23) (stack "East") and a stack of those on the ice divide (B22, B26, B27, B29, B30 and NGRIP) (stack "Divide") (Fig. 5).

Even though there is a similar overall trend, the three records show differences in amplitude and timing of warm and cool events. The correlation between the two sub-stacks is rather low ( $r=0.71$ of 30-year running means). In the 11 th and 12 th centuries, we observe a quasi-anti-correlation between stack "East" and stack "Divide". Even during wellknown climate events such as the Medieval Climate Anomaly (MCA, AD 950-1250; Mann et al., 2009), the Little Ice Age (LIA, 1400-1900; Mann et al., 1998) and the early twentieth century warming (ETCW, AD 1920-1940; Semenov and Latif, 2012), there are significantly different $\delta^{18} \mathrm{O}$ patterns. For example, stack "Divide" shows colder temperatures during AD 1000-1200. Also, during the 16th century we notice substantial differences between the two sub-stacks. In stack "East" events like the AD 1420 or the first part of the LIA show a higher amplitude.

Stack "East" has a higher correlation to the total NG stack $(r=0.96)$ compared to stack "Divide" $(r=0.68)$ for the period AD 994-1994. When looking at the time period AD 1505-1993 with a high number of cores included in both sub-stacks, it can be seen that the correlation coefficients to the total NG stack are almost equal (stack "East": $r=0.95$; stack "Divide": $r=0.90, p<0.1)$. Here, both records reflect the mean changes in $\delta^{18} \mathrm{O}$ for northern Greenland. Differences before AD 1505 may be artifacts of low core numbers even though regional differences in climate conditions cannot be ruled out.

We consider the NG stack to be a climate record that displays the overall climate variation independent of local influences such as topography or accumulation rate. In con- 
trast, results from studies with only one record become less spatially representative, as they may be affected by a lower signal-to-noise ratio and a higher influence of other local non-climate effects.

\subsection{Last millennium climate from a stacked $N G \delta^{18} \mathrm{O}$ record in relation to other proxy records and possible forcing factors}

The NG stack covers the time between AD 753 and AD 1994 (Fig. 5). For a better visualization of decadal- to centennialscale variability, a 30 -year running mean is added. The running mean shows the warmest period around AD 1420 and the coldest at about AD 1680. The isotopically warmest single year during the last 1000 years in northern Greenland was AD 1928, whereas AD 1835 was the coldest.

Distinct decadal- to centennial-scale warm and cold anomalies can be detected in the stacked (Fig. 5) as well as individual $\delta^{18} \mathrm{O}$ records (Fig. 2) and coincide with wellknown climate anomalies (MCA, LIA, ETCW, marked in Fig. 5).

We find a pronounced warm period from $\mathrm{AD} 850$ to 1100 which has its maximum between AD 900 and 1000. This is about 100 years earlier than the described MCA in Mann et al. (2009). The warm period is followed by a quasi-periodical change of warm and cold phases observed approximately every 60 to 80 years until about AD 1600. During this phase, the most distinct warm period is observed around AD 1420.

A longer period of cold temperatures occurred during the 17 th and early 19th century and has already been attributed to the LIA by a prior NGT study that used only four cores (B16, B18, B21 and B29; Fischer et al., 1998c). A cold period in northern Greenland corresponding to the LIA is later than reconstructed for the entire Northern Hemisphere by Mann et al. (1998), with lowest values during AD 1620-1780 and in the first half of the 19th century. Interestingly, the warmest mean values of the last 1000 years at AD 1420 lie within the time frame of the LIA.

A distinct but, compared to other periods, not exceptional warm event in the early 20th century corresponds to the ETCW. Since the 1870s, the values are above the 1000-year mean. At the end of the 20th century, the temperature stagnates at a high mean level. However, as the NGT cores were drilled between AD 1993 and 1995, the warmest years of the recent decades (Wood et al., 2010) are not included in our record.

For the NG stack as well as most of the individual NGT cores, the isotopically warmest periods besides the AD 1420 event were in the 10th and 20th centuries, in particular between AD 1900 and 1950. These years are even warmer than the most recent years covered by the NGT cores (i.e., the 1980s).

To place the results in an Arctic-wide context, we compare our northern Greenland temperature record (NG stack) to ice core records from the Russian Arctic (Akademii Nauk
- AN; Opel et al., 2013), Canada (Agassiz Ice Cap - Agassiz; Vinther et al., 2008), Svalbard (Lomonosovfonna - Lomo; Divine et al., 2011) and southern Greenland (Dye3; Vinther et al., 2006b), as well as a multi-proxy reconstruction of annual Arctic SAT (Arctic2k; Pages 2k Consortium, 2013; Fig. 6) that covers our time period.

Note that some of these time series (Agassiz, Arctic2k) are also stacked records with a wider regional representativeness, whereas others are single records (Dye3, AN, Lomo), which influences the strength of correlation due to different signal-to-noise ratios. For the discussion of the temperature record, we concentrate on the smoothed values (30-year running means).

The strongest correlations with our NG stack are found for the Agassiz and Arctic2k records $(r=0.58$ and 0.66, respectively). For the latter, we have to consider that some of the NGT cores (B16, B18 and B21 on the old timescale) are used to generate this multi-proxy record. In total, 59 records including 16 ice cores were used. NGT cores represent only 3 out of these 59 records. The correlation coefficient between the stacked anomalies of B16, B18 and B21 and the Arctic2k temperature is small $(r=0.24)$, so we can assume that the NGT records do not dominate the reconstruction.

We conclude that a good correlation between the NG stack and the Arctic $2 \mathrm{k}$ record shows that the temperature in northern Greenland generally follows the Arctic-wide mean temperature.

The Lomonosovfonna record is interpreted as a winter record and has only a weak correlation with the NG stack $(r=0.22)$. More summer snow in northern Greenland compared to Lomonosovfonna could be one possible explanation for the weak correlation between both records. While for the other drill sites we have comparable $r$ values for both substacks as for the NG stack, the Lomonosovfonna record has a stronger correlation to stack "East" $(r=0.2)$ than to stack "Divide" $(r=-0.12)$, which supports the argument of different moisture sources or seasonal distribution of snowfall in the northeast of Greenland.

The Lomonosovfonna, Akademii Nauk and Arctic2k records show significantly more enriched $\delta^{18} \mathrm{O}$ values during the MCA. However, smaller events of abnormal warm temperatures during the MCA are observed for Agassiz and Dye3. Our NG stack shows warmer values earlier than the MCA time period given by Mann et al. (1998). We conclude that, further north in the Arctic, the warm events during MCA may be less pronounced or earlier in timing.

The Lomonosovfonna and Arctic2k records show a dominant cold period during the LIA from AD 1580 to 1870. Also, our northern Greenland ice cores, as well as those of Agassiz and Akademii Nauk, reveal distinct LIA cooling periods in contrast to the Dye3 ice core from southern Greenland. Like in our NG stack, the cooling appears in two phases and some decades later than described by Mann et al. (2009). For the NG stack, the younger phase (AD 1800-1850) is of minor amplitude and shorter duration. 


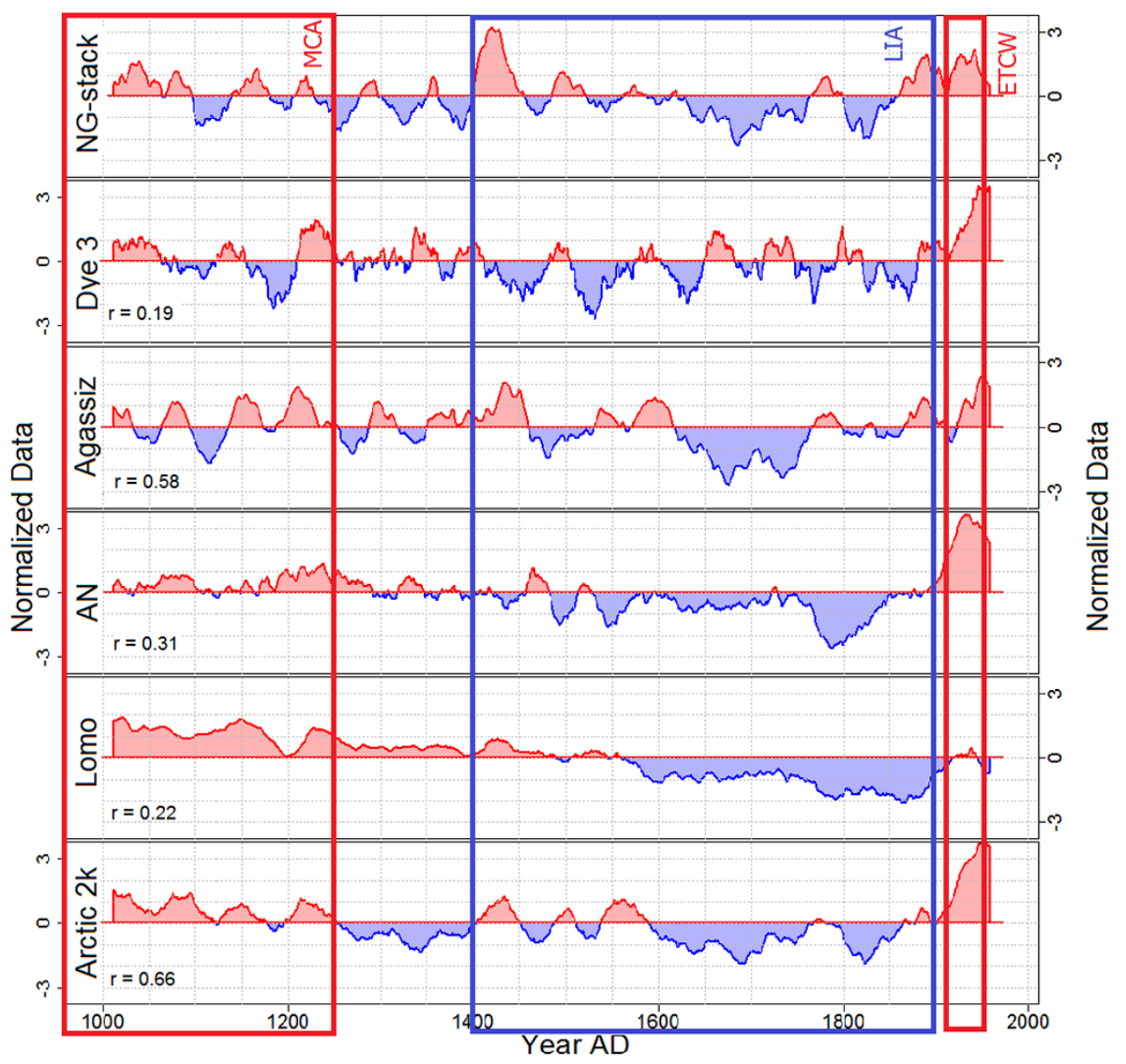

Figure 6. Thirty-year running mean for $\delta^{18} \mathrm{O}$ values from different Arctic regions - northern Greenland (NG stack, this study), southern Greenland (Dye3; Vinther et al., 2006b), Canada (Agassiz Ice Cap, Agassiz; Vinther et al., 2008), Russian Arctic (Akademii Nauk, AN; Opel et al., 2013) and Svalbard (Lomonosovfonna, Lomo, Divine et al., 2011) - as well as a reconstructed record (Arctic2k; Pages 2k Consortium, 2013). All records are given on $z$-level scales (centered and normalized data). The correlation coefficient for the smoothed values with regard to our stack is also given.

Between AD 1920 and 1940, there was a major warming period in the Arctic, known as the ETCW, which was observed in all records shown here. Chylek et al. (2006) determined from meteorological data that the 1920-1930 warming was stronger than the 1995-2005 warming. For the NG stack and Akademii Nauk record, the ETCW was warmer than the second half of the 20th century, which distinguishes them from other shown records. The ETCW is assumed to be independent of external forcing but caused by internal climate variability, in particular sea-ice-atmosphere feedbacks (Wood and Overland, 2010). This led us to conclude that northern Greenland may also be a good place to study forcing-independent (i.e., internal) climate changes.

However, natural external forcing (i.e., insolation, solar irradiance and volcanic eruptions) is assumed to influence the temperature that can be studied from northern Greenland's ice cores.

In general, higher solar activity causes higher temperatures (as during the MCA), whereas cold periods (e.g., LIA) are dominated by lower solar activity (Ammann et al., 2007).
Based on some of the NGT records (B16, B18, B21 and B29), Fischer et al. (1998c) explained most of the long-term variation in northern Greenland through changes in solar activity.

Volcanism causes strong negative radiative forcing (Robock, 2000). It is assumed that volcanic eruptions inject large quantities of sulfur-rich gases into the stratosphere and global climate can be cooled by $0.2-0.3^{\circ} \mathrm{C}$ for several years after the eruption (Zielinski, 2000). Results from Crowley (2000) indicate that volcanism generally explains roughly $15-30 \%$ of the variability in global temperatures.

Miller et al. (2012) argued that century-scale cold summer anomalies, of which the LIA represents the coldest, occur because natural forcing is either weak or, in the case of volcanism, short-lived. Pages 2k Consortium (2013) shows that periods with strong volcanic activity correspond to a reduced mean temperature. The LIA may be therefore caused by a 50-year-long episode of volcanism and kept persistently cold because of ocean feedback and a summer insolation minimum. 


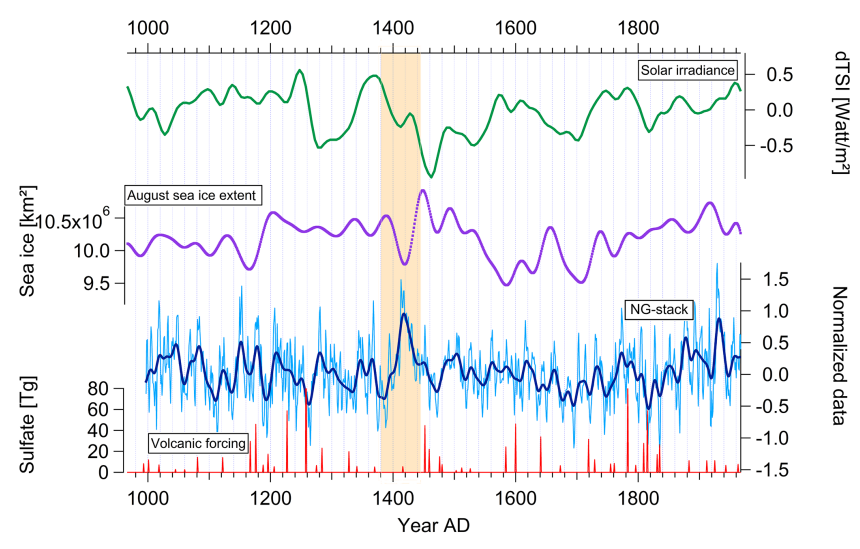

Figure 7. The northern Greenland stack (NG stack; blue: annual; dark blue: smoothed) is shown with possible forcing factors. Green represents the reconstructed total solar irradiance (Steinhilber et al., 2009), purple the reconstructed August Arctic sea-ice extent (Kinnard et al., 2011), and red at the bottom the stratospheric sulfate aerosol injection for the Northern Hemisphere (Gao et al., 2008). All values are 40-year low-pass-filtered. The discussed AD 1420 event is marked in beige.

Between about AD 1100 and 1600 we observe quasiperiodic (60-80 a) cold and warm anomalies in the NG stack which are not present in the other Arctic records shown (Fig. 6). The main period determined using Fourier decomposition between $\mathrm{AD} 1100$ and 1600 for 30-year running mean smoothed values is calculated with $76.31 \mathrm{a}$.

The Atlantic Multidecadal Oscillation (AMO) could be one possible influence causing these low-frequency oscillations. Chylek et al. (2012) explain that the AMO is visible in $\delta^{18} \mathrm{O}$ values from central Greenland. As the AMO index reconstruction (Gray et al., 2004) does not cover the time between AD 1100 and 1600, we can only speculate about an influence in that time due to the similar periodicity. For the time period AD 1567-1990, the correlation between the NG stack and the AMO index is weak $(r=0.06)$, which might be due to the uncertainties in historical AMO data. However, after AD 1800 we observe a higher correlation coefficient $(r=0$. $66, p<0.05)$ implying a possible relation.

One of these warmer periods is at about $\mathrm{AD} 1420 \pm 20$, an abnormal warm event which is observed in our northern Greenland record and has not been pointed out in other ice core studies before. The event is observable in all nine NGT cores covering this time (Fig. 2) as well as in NGRIP but not in the isotope records from southern Greenland such as the Dye3 ice core (Fig. 6). One reason here might be the specific geographical position in the north.

Furthermore, we observe a difference between the Canadian and Russian Arctic regarding the 1420 event. Unlike the Russian Akademii Nauk ice core, the $\delta^{18} \mathrm{O}$ values of the Agassiz cores from Ellesmere Island also show a tendency towards more enriched values in that period but which is not as strong as in northern Greenland.
The fact that the 1420 event is not clearly noticeable in other surrounding Arctic ice cores emphasizes that this event may have occurred on a smaller regional scale. However, it seems to have been of dominant influence and is also reflected in a smaller warming for the Arctic2k record (Fig. 6).

The spatial distribution of the 1420 event in northern Greenland is mapped in Fig. 3b. The event is strongest in the upper north and shows a different pattern than the $\delta^{18} \mathrm{O}$ anomalies of the 1920/1930 warm phase, which is also attributed to internal variability and is strongest in the northeast of Greenland.

Figure 7 shows possible forcing factors that might be related to the AD 1420 event. According to the reconstructed total solar irradiance record of Steinhilber et al. (2009), there was no solar maximum observed for AD 1420 that could explain the warmer temperatures in northern Greenland. As we see no forcing anomaly, we interpret the 1420 event as likely be caused by internal Arctic climate dynamics with a seaice-atmosphere feedback.

Box (2002) argued that climate variability in Greenland is linked to the North Atlantic Oscillation (NAO), volcanism and sea-ice extent. NAO (Vinther et al., 2003) is calculated to be weakly reflected $(r=-0.2, p<0.01)$ in the NG stack, similar to the results of White et al. (1997) for summit ice cores, whereas none of the single NGT records is significantly correlated $(p<0.05)$ with the NAO index. The NG stack has an increased signal-to-noise level, which is why the correlation here might be clearer than from individual records. Also, the sub-stacks of the records on the ice divide (stack "Divide") as well as those east (stack "East") are significantly correlated $(r=-0.19$ and $-0.17, p<0.05)$ with the NAO index. The cores east of the main ice divide are expected to be out of the major cyclonic track. We conclude that NAO is not of major importance for northern Greenland $\delta^{18} \mathrm{O}$ values.

Around AD 1420, an anti-correlation between sea-ice extent in the Arctic Ocean (Kinnard et al., 2011) and the $\delta^{18} \mathrm{O}$ values is observed (Fig. 7). The sea-ice extent reconstruction of Kinnard et al. (2011) is based on 69 proxy records, of which 22 are $\delta^{18} \mathrm{O}$ records. Out of these $22 \delta^{18} \mathrm{O}$, records 5 (NGRIP, B16, B18, B21 and B26) are also used in our NG stack. We do not expect circular reasoning in the interpretation of the 1420 event because B16 and B26 do not reach the age of AD 1420 and we do not see a strong anti-correlation during any other time period.

The sea ice in the Arctic Ocean shows a recession only during that warm period in northern Greenland. A diminished sea-ice extent would cause higher temperatures on a regional scale and would increase the amount of water vapor from local sources. Therefore, compared to distant sources, more isotopically enriched moisture (Sime et al., 2013) may contribute to precipitation in northern Greenland, in particular east of the main ice divide.

However, we do not see any direct relationship between sea-ice extent and our NG stack during the rest of time, which 
does not exclude the relationship between sea-ice extent and $\delta^{18} \mathrm{O}$ in northern Greenland. The sea-ice reconstruction used is Arctic-wide, which means that the climatic events of regional extent, like an additional moisture source for northern Greenland's $\delta^{18} \mathrm{O}$, do not always have to be reflected. Nevertheless, the recent NEEM $\delta^{18} \mathrm{O}$ record from northwestern Greenland also shows a generally close relationship with the Labrador Sea/Baffin Bay sea-ice extent (Masson-Delmotte et al., 2015; Steen-Larsen et al., 2011).

\section{Conclusions}

With the full set of the NGT records, it was, for the first time, possible to describe regional differences in the $\delta^{18} \mathrm{O}$ values in northern Greenland over the last 1000 years.

Because of the ice sheet topography we see a clear eastto-west difference in northern Greenland $\delta^{18} \mathrm{O}$ distribution. In total, $12 \%$ of the spatial $\delta^{18} \mathrm{O}$ variability is attributed to ice sheet topography. The east-to-west gradient is larger than the north-to-south gradient. We find a more pronounced persistence of warm or cold events east of the main ice divide and assume more stable climate conditions there. The eastern part is more influenced by local effects like changes in the Arctic Ocean. However, these findings need to be supported by the results of climate models. For the first time, a local warm event at AD $1420 \pm 20$ has been pointed out. We assume an atmosphere-sea-ice feedback to be one possible reason for this event.

Due to the shadowing effect of the main ice divide we find the lowest accumulation rates in the northeast, whereas the lowest mean $\delta^{18} \mathrm{O}$ values are found east of the main ice divide north of the summit. The lowest $\delta^{18} \mathrm{O}$ mean values seem to be independent of accumulation rate.

We have presented a new 1000-year stacked $\delta^{18} \mathrm{O}$ record for northern Greenland covering $10 \%$ of the area of Greenland. We found this NG stack to be representative of the northern Greenland temperature.

Northern Greenland $\delta^{18} \mathrm{O}$ represents known climatic variations of the last millennium. We see a warm MCA and can derive distinct LIA cooling from our NG stack.

The results of single-site ice core studies are likely weakened by the finding that there is only $22 \%$ common variability in the 13 NGT cores.

The solar activity and internal Arctic climate dynamics are likely the main factors influencing the temperature in northern Greenland. In contrast, we could not find a general cooling effect of volcanic eruptions in our data.

Acknowledgements. Stefanie Weißbach was financed by the "Earth System Science Research School (ESSReS)", an initiative of the Helmholtz Association of German Research Centres (HGF) at the Alfred Wegener Institute (AWI), Helmholtz Centre for Polar and Marine Research.

Anna Wegner acknowledges REKLIM for funding.
This study contributes to the Eurasian Arctic Ice 4k project funded by the Deutsche Forschungsgemeinschaft (grant OP 217/2-1 awarded to Thomas Opel).

Many thanks to the drill and lab team who have measured the $\delta^{18} \mathrm{O}$ (76.930 samples) over more than 20 years. We also thank Johannes Freitag and Katja Instenberg for high-resolution (CT) density measurements; Martin Rückamp for compiling the maps; Martin Werner, Thomas Laepple and Johannes Freitag for helpful discussions that improved the manuscript; and Kirstin Meyer for checking the language.

We acknowledge the constructive comments from the two anonymous referees and the editor.

The NG $\delta^{18} \mathrm{O}$ stack as well as the $\delta^{18} \mathrm{O}$ and accumulation records of all individual NGT ice cores used in the paper is available at doi:10.1594/PANGAEA.849161.

Edited by: V. Masson-Delmotte

\section{References}

Ammann, C. M., Joos, F., Schimel, D. S., Otto-Bliesner, B. L., and Tomas, R. A.: Solar influence on climate during the past millennium: results from transient simulations with the NCAR Climate System Model, P. Natl. Acad. Sci. USA, 104, 3713-3718, 2007.

Appenzeller, C., Schwander, J., Sommer, S., and Stocker, T. F.: The North Atlantic Oscillation and its imprint on precipitation and ice accumulation in Greenland, Geophys. Res. Lett., 25, 11, 19391942, 1998.

Bamber, J. L., Griggs, J. A., Hurkmans, R. T. W. L., Dowdeswell, J. A., Gogineni, S. P., Howat, I., Mouginot, J., Paden, J., Palmer, S., Rignot, E., and Steinhage, D.: A new bed elevation dataset for Greenland, The Cryosphere, 7, 499-510, doi:10.5194/tc-7-4992013, 2013.

Benson, C. S.: Greenland snow pit and core stratigraphic data 1952, 1953, 1954, 1955, U.S. Army Corps of Engineers Snow Ice and Permafrost Res, 70, 39-47, 1962.

Bigler, M., Wagenbach, D., Fischer, H., Kipfstuhl, J., Miller, H., Sommer, S., and Stauffer, B.: Sulphate record from a northeast Greenland ice core over the last 1200 years based on continuous flow analysis, in: Annals of Glaciology, vol. 35, edited by: Wolff, E. W., Int. Glaciological Soc., Cambridge, 250-256, 2002.

Box, J. E.: Survey of Greenland instrumental temperature records: 1873-2001, Int. J. Climatol., 22, 1829-1847, 2002.

Box, J. E., Yang, L., Bromwich, D. H., and Bai, L.-S.: Greenland Ice Sheet Surface Air Temperature Variability: 1840-2007*, J. Climate, 22, 4029-4049, 2009.

Buchardt, S. L., Clausen, H. B., Vinther, B. M., and Dahl-Jensen, $\mathrm{D} .:$ Investigating the past and recent $\delta^{18} \mathrm{O}$-accumulation relationship seen in Greenland ice cores, Clim. Past, 8, 2053-2059, doi:10.5194/cp-8-2053-2012, 2012.

Buizert, C., Gkinis, V., Severinghaus, J. P., He, F., Lecavalier, B. S., Kindler, P., Leuenberger, M., Carlson, A. E., Vinther, B., Masson-Delmotte, V., White, J. W. C., Liu, Z., Otto-Bliesner, B., and Brook, E. J.: Greenland temperature response to climate forcing during the last deglaciation, Science, 345, 1177-1180, 2014.

Bull, C.: Snow accumulation in north Greenland, J. Glaciol., 3, 237248, 1958. 
Chen, Q. S., Bromwich, D. H., and Bai, L. S.: Precipitation over Greenland retrieved by a dynamic method and its relation to cyclonic activity, J. Climate, 10, 839-870, 1997.

Chylek, P., Dubey, M. K., and Lesins, G.: Greenland warming of 1920-1930 and 1995-2005, Geophys. Res. Lett., 33, L11707, doi:10.1029/2006GL026510, 2006.

Chylek, P., Folland, C., Frankcombe, L., Dijkstra, H., Lesins, G., and Dubey, M.: Greenland ice core evidence for spatial and temporal variability of the Atlantic Multidecadal Oscillation, Geophys. Res. Lett., 39, L09705, doi:10.1029/2012GL051241, 2012.

Crowley, T. J.: Causes of Climate Change Over the Past 1000 Years, Science, 289, 270-277, 2000.

Dahl-Jensen, D., Mosegaard, K., Gundestrup, N., Clow, G. D., Johnsen, S. J., Hansen, A. W., and Balling, N.: Past temperatures directly from the Greenland Ice Sheet, Science, 282, 268-271, 1998.

Dansgaard, W.: The $\mathrm{O}^{18}$-abundance in fresh water, Geochim. Cosmochim. Ac., 6, 241-260, 1954.

Dansgaard, W.: Stable isotopes in precipitation, Tellus, 16, 436468, 1964.

Dansgaard, W., Johnsen, S. J., and Moeller, J.: One Thousand Centuries of Climatic Record from Camp Century on the Greenland Ice Sheet, Science, 166, 377-380, 1969.

Divine, D., Isaksson, E., Martma, T., Meijer, H. A. J., Moore, J., Pohjola, V., van de Wal, R. S. W., and Godtliebsen, F.: Thousand years of winter surface air temperature variations in Svalbard and northern Norway reconstructed from ice core data, Polar Res., 30, 7379, doi:10.3402/polar.v30i0.7379, 2011.

Fischer, H. and Mieding, B.: A 1,000-year ice core record of interannual to multidecadal variations in atmospheric circulation over the North Atlantic, Clim. Dynam., 25, 65-74, 2005.

Fischer, H., Wagenbach, D., and Kipfstuhl, J.: Sulfate and nitrate firn concentrations on the Greenland ice sheet: 1. Large-scale geographical deposition changes, J. Geophys. Res., 103, 2192721930, 1998a.

Fischer, H., Wagenbach, D., and Kipfstuhl, J.: Sulfate and nitrate firn concentrations on the Greenland ice sheet: 2. Temporal anthropogenic deposition changes, J. Geophys. Res.-Atmos., 103, 21935-21942, 1998b.

Fischer, H., Werner, M., Wagenbach, D., Schwager, M., Thorsteinnson, T., Wilhelms, F., Kipfstuhl, J., and Sommer, S.: Little Ice Age clearly recorded in northern Greenland ice cores, Geophys. Res. Lett., 25, 1749-1752, 1998c.

Fisher, D. A., Reeh, N., and Clausen, H. B.: Stratigraphic noise in time series derived from ice cores, Ann. Glaciol, 7, 76-83, 1985.

Freitag, J., Kipfstuhl, S., and Laepple, T.: Core-scale radioscopic imaging: a new method reveals density \& calcium link in Antarctic firn, J. Glaciol., 59, 1009-1014, 2013.

Friedmann, A., Moore, J. C., Thorsteinnson, T., Kipfstuhl, J., and Fischer, H.: A 1200 year record of accumulation from northern Greenland, Ann. Glaciol, 21, 19-25, 1995.

Gao, C., Robock, A., and Ammann, C.: Volcanic forcing of climate over the past 1500 years: An improved ice core-based index for climate models, J. Geophys. Res.-Atmos., 113, D23111, doi:10.1029/2008JD010239, 2008.

Gray, S. T., Graumlich, L. J., Betancourt, J. L., and Pederson, G. T.: A tree-ring based reconstruction of the Atlantic Multidecadal Oscillation since 1567 A.D, Geophys. Res. Lett., 31, L12205, doi:10.1029/2004GL019932, 2004.
Grootes, P. M. and Stuiver, M.: Oxygen 18/16 variability in Greenland snow and ice with $10^{-3}$ - to $10^{5}$-year time resolution, J. Geophys. Res.-Oceans, 102, 26455-26470, 1997.

Grootes, P. M., Stuiver, M., White, J. W. C., Johnsen, S., and Jouzel, J.: Comparison of oxygen isotope records from the GISP2 and GRIP Greenland ice cores, Nature, 366, 552-554, 1993.

Hanna, E., Jónsson, T., and Box, J. E.: An analysis of Icelandic climate since the nineteenth century, Int. J. Climatol., 24, 1193 1210, 2004.

Isaksson, E., Kohler, J., Pohjola, V., Moore, J. C., Igarashi, M., Karlöf, L., Martma, T., Meijer, H. A. J., Motoyama, H., Vaikmäe, R., and Van de Wal, R. S. W.: Two ice-core $\delta^{18} \mathrm{O}$ records from Svalbard illustrating climate and sea-ice variability over the last 400 years, Holocene, 15, 501-509, 2005.

Johnsen, S. J., Dansgaard, W., and White, J. W. C.: The origin of Arctic precipitation under present and glacial conditions, Tellus Ser. B, 41, 452-468, 1989.

Johnsen, S. J., Hammer, C. U., Dansgaard, W., Gundestrup, N. S., and Clausen, H. B.: The Eem stable isotope record along the GRIP ice core and its interpretation, Quaternary Res., 42, 117$124,1995$.

Johnsen, S. J., Clausen, H. B., Cuffey, K. M., Hoffmann, G., Schwander, J., and Creyts, T.: Diffusion of stable isotopes in polar firn and ice: the isotope effect in firn diffusion, in: Physics of Ice Core Records, Hokkaido University, Place Hokkaido, 121140, 2000.

Jónsson, T.: the observations of Jon Thorsteinsson in Nes and Reykjavik 1820-1854, Icel. Met. Office Report, Reykjavik, 1989.

Jouzel, J., Alley, R. B., Cuffey, K. M., Dansgaard, W., Grootes, P., Hoffmann, G., Johnsen, S. J., Koster, R. D., Peel, D., Shuman, C. A., Stievenard, M., Stuiver, M., and White, J.: Validity of the temperature reconstruction from water isotopes in ice cores, J. Geophys. Res.-Oceans, 102, 26471-26487, 1997a.

Jouzel, J., Froehlich, K., and Schotterer, U.: Deuterium and oxygen18 in present-day precipitation: data and modelling, Hydrogeological Science, 42, 747-763, $1997 \mathrm{~b}$.

Jouzel, J. and Merlivat, L.: Deuterium and O-18 in precipitationModelling of the isotopic effects during snow formation, J. Geophys. Res.-Atmos., 89, 1749-1757, 1984.

Kaufmann, P., Federer, U., Hutterli, M. A., Bigler, M., Schüpbach, S., Ruth, U., Schmitt, J., and Stocker, T. F.: An Improved Continuous Flow Analysis System for High-Resolution Field Measurements on Ice Cores, Environ. Sci. Technol., 42, 8044-8050, doi:10.1021/es8007722, 2008.

Kinnard, C., Zdanowicz, C. M., Fisher, D. A., Isaksson, E., de Vernal, A., and Thompson, L. G.: Reconstructed changes in Arctic sea ice over the past 1,450 years, Nature, 479, 509-512, 2011.

Koch, J. P. and Wegener, A.: Wissenschaftliche Ergebnisse der dänischen Expedition nach Dronning Louises-Land und quer über das Inlandeis von Nordgrönland 1912-13, Reitzel, 1930.

Lavigne, F., Degeai, J.-P., Komorowski, J.-C., Guillet, S., Robert, V., Lahitte, P., Oppenheimer, C., Stoffel, M., Vidal, C. M., Surono, Pratomo, I., Wassmer, P., Hajdas, I., Hadmoko, D. S., and de Belizal, E.: Source of the great A.D. 1257 mystery eruption unveiled, Samalas volcano, Rinjani Volcanic Complex, Indonesia, P. Natl. Acad. Sci., 110, 16742-16747, 2013.

Mann, M. E., Bradley, R. S., and Hughes, M. K.: Global-scale temperature patterns and climate forcing over the past six centuries, Nature, 392, 779-787, 1998. 
Mann, M. E., Zhang, Z., Rutherford, S., Bradley, R. S., Hughes, M. K., Shindell, D., Ammann, C., Faluvegi, G., and Ni, F.: Global Signatures and Dynamical Origins of the Little Ice Age and Medieval Climate Anomaly, Science, 326, 1256-1260, 2009.

Masson-Delmotte, V., Steen-Larsen, H. C., Ortega, P., Swingedouw, D., Popp, T., Vinther, B. M., Oerter, H., Sveinbjornsdottir, A. E., Gudlaugsdottir, H., Box, J. E., Falourd, S., Fettweis, X., Gallée, H., Garnier, E., Gkinis, V., Jouzel, J., Landais, A., Minster, B., Paradis, N., Orsi, A., Risi, C., Werner, M., and White, J. W. C.: Recent changes in north-west Greenland climate documented by NEEM shallow ice core data and simulations, and implications for past-temperature reconstructions, The Cryosphere, 9, 14811504, doi:10.5194/tc-9-1481-2015, 2015.

Merlivat, L. and Jouzel, J.: Global climatic interpretation of the deuterium-oxygen 18 relationship for precipitation, J. Geophys. Res.-Oc. Atmos., 84, 5029-5033, 1979.

Mieding, B.: Reconstruction of millennial aerosol-chemical ice core records from the northeast Greenland: Quantification of temporal changes in atmospheric circulation, emission and deposition, Reports on Polar and Marine Reports, 513, Alfred Wegener Institute for Polar and Marine Research, Bremerhaven, 2005.

Miller, G. H., Geirsdóttir, Á., Zhong, Y., Larsen, D. J., OttoBliesner, B. L., Holland, M. M., Bailey, D. A., Refsnider, K. A., Lehman, S. J., Southon, J. R., Anderson, C., Björnsson, H., and Thordarson, T.: Abrupt onset of the Little Ice Age triggered by volcanism and sustained by sea-ice/ocean feedbacks, Geophys. Res. Lett., 39, L02708, doi:10.1029/2011GL050168, 2012.

Newhall, C. G. and Self, S.: The volcanic explosivity index (VEI) an estimate of explosive magnitude for historical volcanism, J. Geophys. Res.-Oceans, 87, 1231-1238, 1982.

North Greenland Ice Core Project Members: Andersen, K. K., Azuma, N., Barnola, J.-M., Bigler, M., Biscaye, P., Caillon, N., Chappellaz, J., Clausen, H. B., Dahl-Jensen, D., Fischer, H., Flückiger, J., Fritzsche, D., Fujii, Y., Goto-Azuma, K., Grønvold, K., Gundestrup, N. S., Hansson, M., Huber, C., Hvidberg, C. S., Johnsen, S. J., Jonsell, U., Jouzel, J., Kipfstuhl, S., Landais, A., Leuenberger, M., Lorrain, R., Masson-Delmotte, V., Miller, H., Motoyama, H., Narita, H., Popp, T., Rasmussen, S. O., Raynaud, D., Röthlisberger, R., Ruth, U., Samyn, D., Schwander, J., Shoji, H., Siggard-Andersen, M.-L., Steffensen, J. P., Stocker, T. F., Sveinbjörnsdóttir, A. E., Svensson, A., Takata, M., Tison, J.L., Thorsteinsson, T., Watanabe, O., Wilhelms, F., and White, J. W. C.: High-resolution record of Northern Hemisphere climate extending into the last interglacial period, Nature, 431, 147-151, 2004.

Ohmura, A.: New temperature distribution maps for Greenland, Zeitschrift für Gletscherkunde und Glaziologie, 35, 1-20, 1987.

Opel, T., Fritzsche, D., and Meyer, H.: Eurasian Arctic climate over the past millennium as recorded in the Akademii Nauk ice core (Severnaya Zemlya), Clim. Past, 9, 2379-2389, doi:10.5194/cp9-2379-2013, 2013.

Ortega, P., Swingedouw, D., Masson-Delmotte, V., Risi, C., Vinther, B., Yiou, P., Vautard, R., and Yoshimura, K.: Characterizing atmospheric circulation signals in Greenland ice cores: insights from a weather regime approach, Clim. Dynam., 43, 2585-2605, 2014.

Pages 2k Consortium: Continental-scale temperature variability during the past two millennia, Nat. Geosci., 6, 339-346, 2013.
Pinzer, B. R., Schneebeli, M., and Kaempfer, T. U.: Vapor flux and recrystallization during dry snow metamorphism under a steady temperature gradient as observed by time-lapse microtomography, The Cryosphere, 6, 1141-1155, doi:10.5194/tc-61141-2012, 2012.

Robock, A.: Volcanic eruptions and climate, Rev. Geophys., 38, 191-219, 2000.

Schwager, M.: Ice core analysis on the spatial and temporal variability of temperature and precipitation during the late Holocene in North Greenland, Reports on Polar and Marine Research, 362, Alfred Wegener Institute for Polar and Marine Research, Bremen, 2000.

Semenov, V. A. and Latif, M.: The early twentieth century warming and winter Arctic sea ice, The Cryosphere, 6, 1231-1237, doi:10.5194/tc-6-1231-2012, 2012.

Severinghaus, J. P., Sowers, T., Brook, E. J., Alley, R. B., and Bender, M. L.: Timing of abrupt climate change at the end of the Younger Dryas interval from thermally fractionated gases in polar ice, Nature, 391, 141-146, 1998.

Sigl, M., McConnell, J. R., Layman, L., Maselli, O., McGwire, K., Pasteris, D., Dahl-Jensen, D., Steffensen, J. P., Vinther, B., Edwards, R., Mulvaney, R., and Kipfstuhl, S.: A new bipolar ice core record of volcanism from WAIS Divide and NEEM and implications for climate forcing of the last 2000 years, J. Geophys. Res.-Atmos., 118, 1151-1169, 2013.

Sime, L. C., Risi, C., Tindall, J. C., Sjolte, J., Wolff, E. W., MassonDelmotte, V., and Capron, E.: Warm climate isotopic simulations: what do we learn about interglacial signals in Greenland ice cores?, Quaternary Sci. Rev., 67, 59-80, 2013.

Steen-Larsen, H. C., Masson-Delmotte, V., Sjolte, J., Johnsen, S. J., Vinther, B. M., Bréon, F. M., Clausen, H. B., Dahl-Jensen, D., Falourd, S., Fettweis, X., Gallée, H., Jouzel, J., Kageyama, M., Lerche, H., Minster, B., Picard, G., Punge, H. J., Risi, C., Salas, D., Schwander, J., Steffen, K., Sveinbjörnsdóttir, A. E., Svensson, A., and White, J.: Understanding the climatic signal in the water stable isotope records from the NEEM shallow firn/ice cores in northwest Greenland, J. Geophys. Res.-Atmos., 116, D06108, doi:10.1029/2010JD014311, 2011.

Steen-Larsen, H. C., Masson-Delmotte, V., Hirabayashi, M., Winkler, R., Satow, K., Prié, F., Bayou, N., Brun, E., Cuffey, K. M., Dahl-Jensen, D., Dumont, M., Guillevic, M., Kipfstuhl, S., Landais, A., Popp, T., Risi, C., Steffen, K., Stenni, B., and Sveinbjörnsdottír, A. E.: What controls the isotopic composition of Greenland surface snow?, Clim. Past, 10, 377-392, doi:10.5194/cp-10-377-2014, 2014.

Steffensen, J. P., Andersen, K. K., Bigler, M., Clausen, H. B., DahlJensen, D., Fischer, H., Goto-Azuma, K., Hansson, M., Johnsen, S. J., Jouzel, J., Masson-Delmotte, V., Popp, T., Rasmussen, S O., Röthlisberger, R., Ruth, U., Stauffer, B., Siggaard-Andersen, M. L., Sveinbjornsdottir, A. E., Svensson, A., and White, J. W.: High-resolution Greenland ice core data show abrupt climate change happens in few years, Science, 321, 680-684, 2008.

Steinhilber, F., Beer, J., and Fröhlich, C.: Total solar irradiance during the Holocene, Geophys. Res. Lett., 36, L19704, doi:1029/2009GL040142, 2009.

Vinther, B. M., Andersen, K. K., Hansen, A. W., Schmith, T., and Jones, P. D.: Improving the Gibraltar/Reykjavik NAO index, Geophys. Res. Lett., 30, 2222, doi:10.1029/2003GL018220, 2003. 
Vinther, B. M., Andersen, K. K., Jones, P. D., Briffa, K. R., and Cappelen, J.: Extending Greenland temperature records into the late eighteenth century, J. Geophys. Res.-Atmos., 111, D11105, doi:10.1029/2005JD006810, 2006a.

Vinther, B. M., Clausen, H. B., Johnsen, S. J., Rasmussen, S. O., Andersen, K. K., Buchardt, S. L., Dahl-Jensen, D., Seierstad, I. K., Siggaard-Andersen, M. L., Steffensen, J. P., Svensson, A., Olsen, J., and Heinemeier, J.: A synchronized dating of three Greenland ice cores throughout the Holocene, J. Geophys. Res.Atmos., 111, D13102, doi:10.1029/2005JD006921, 2006b.

Vinther, B. M., Clausen, H. B., Fisher, D. A., Koerner, R. M., Johnsen, S. J., Andersen, K. K., Dahl-Jensen, D., Rasmussen, S. O., Steffensen, J. P., and Svensson, A. M.: Synchronizing ice cores from the Renland and Agassiz ice caps to the Greenland Ice Core Chronology, J. Geophys. Res.-Atmos., 113, D08115, doi:10.1029/2007JD009143, 2008.

Vinther, B. M., Buchardt, S. L., Clausen, H. B., Dahl-Jensen, D., Johnsen, S. J., Fisher, D. A., Koerner, R. M., Raynaud, D., Lipenkov, V., Andersen, K. K., Blunier, T., Rasmussen, S. O., Steffensen, J. P., and Svensson, A. M.: Holocene thinning of the Greenland ice sheet, Nature, 461, 385-388, 2009.

Vinther, B. M., Jones, P. D., Briffa, K. R., Clausen, H. B., Andersen, K. K., Dahl-Jensen, D., and Johnsen, S. J.: Climatic signals in multiple highly resolved stable isotope records from Greenland, Quaternary Sci. Rev., 29, 522-538, 2010.
Weißbach, S., Wegener, A., and Kipfstuhl, J.: Snow accumulation in North Greenland over the last millennium, in: Towards an interdisciplinary approach in earth system science, edited by: Lohmann, G., Meggers, H., Unnithan, V., Wolf-Gladrow, D., Notholt, J., and Bracher, A., Springer Earth System Science, London, 197-205, 2015.

Werner, M.: Vergleichende Studie ueber die Verteilung vulkanogener Spurenstoffdepositionen in Nord-Ost-Groenland, Diplom, Institut fuer Umweltphysik, Heidelberg, 85 pp., 1995.

White, J. W. C., Barlow, L. K., Fisher, D., Grootes, P., Jouzel, J., Johnsen, S. J., Stuiver, M., and Clausen, H.: The climate signal in the stable isotopes of snow from Summit, Greenland: Results of comparisons with modern climate observations, J. Geophys. Res.-Oceans, 102, 26425-26439, 1997.

Wilhelms, F.: Leitfähigkeits- und Dichtemessung an Eisbohrkernen, Reports on Polar and Marine Research, 191, Alfred Wegener Institute for Polar and Marine Research, Bremerhaven, 1996.

Wood, K. R. and Overland, J. E.: Early 20th century Arctic warming in retrospect, Int. J. Climatol., 30, 1269-1279, 2010.

Wood, K. R., Overland, J. E., Jónsson, T., and Smoliak, B. V.: Air temperature variations on the Atlantic-Arctic boundary since 1802, Geophys. Res. Lett., 37, L17708, doi:10.1029/2010GL044176, 2010.

Zielinski, G. A.: Use of paleo-records in determining variability within the volcanism-climate system, Quaternary Sci. Rev., 19, 417-438, 2000. 